\title{
Exhaustive Overview of Dietary Plant Lectins: Prospective Importance in the Mediterranean Diet
}

\author{
Ian F Pryme ${ }^{1 *}$ and Truls M Aarra ${ }^{2}$ \\ ${ }^{1}$ Department of Biomedicine, University of Bergen, Bergen \\ ${ }^{2}$ Lectinect AS, Nygårdsgate Bergen, Bergen \\ *Corresponding author: Ian F Pryme, University of Bergen, Department of Biomedicine, Jonas Liesvei 91 N-5009 Bergen, Norway. \\ To Cite This Article: Ian F Pryme, Truls M Aarra. Exhaustive Overview of Dietary Plant Lectins: Prospective Importance in the Mediterranean \\ Diet. Am J Biomed Sci \& Res. 2021 - 13(4). AJBSR.MS.ID.001883. DOI: 10.34297/AJBSR.2021.13.001883.
}

Received: 䟧 July 02, 2021; Published: 㘹 July 12, 2021

\begin{abstract}
Stillmark reported in 1888 that castor bean extracts were able to agglutinate red blood cells from different species [1]. The seed extracts were found to contain haemagglutinating proteins, defined as agglutinins. Haemagglutinins are now known as lectins, a term proposed many years ago. Lectins are a very heterogeneous group of proteins of non-immune origin and have gone through several definition steps resulting in lesser strictness over the years. Some years ago, Van Damme defined lectins as: "carbohydrate-binding proteins possessing at least one non-catalytic domain, which bind reversibly to a specific mono- or oligosaccharide" [2]. The continuous discovery of new and diverse lectins with similarities found in several different classes of proteins seems to call for even less strict definitions in the future. Maybe the most accurate lectin definition would simply be: "proteins that specifically bind or cross-bind carbohydrates". Lectins are becoming more and more interesting as components of our diet, and it is interesting to note that in the U.S. News and World Report of 2020 the Mediterranean diet has been named as the best overall healthy diet [3]. The diet is well-known for its high content of vegetables, fruits and nuts and whole grains. This review examines our current knowledge of its importance for the Mediterranean diet.
\end{abstract}

Keywords: Lectins, Beneficial effects on health, Mediterranean diet, Cancer

\section{Introduction}

Lectins are widespread in the plant kingdom, occurring in seeds and all kinds of vegetative tissues, and often take part in the plants defence system against predators such as insects, worms etc [4]. To prevent the plant being fed on, lectins are not very tasteful, and severely interfere with digestive processes in insects and worms. Lectins and many other low molecular weight components in foodstuffs are thus called antinutrients because they often have a negative impact on the nutritional value of diets containing them. As biologically active proteins, lectins are very seldom harmful. Some are able to modify and sometimes improve gut function and body metabolism. They can also alter health status as well [5]. Animal lectins, on the other hand, are usually secreted from the cells where they may participate in cell-cell-interactions, recognition of immune defence systems, immunoregulation and prohibition of autoimmunity [6-8]. Due to the homology between plant and animal lectins, it is likely that the dietary plant lectins to some extent can mimic and amplify the effects normally exerted by their lectin counterparts produced by the animals themselves.

A large number of plant, animal and microbe lectins have now been isolated [9-17]. Lectins are widespread in the plant kingdom (fruits, nuts, vegetables), occurring in seeds and all kinds of vegetative tissues, and often take part in the plants defence system against predators such as insects, worms etc. In many cases lectins severely interfere with digestive processes in such predators. Lectins and many other low molecular weight components in foodstuffs are thus called antinutrients because they often have a negative impact on the nutritional value of diets containing them. However, most of the antinutritional effects can be eliminated or substantially reduced with proper storage, heat treatment, soaking, and germination. As biologically active proteins some are able to modify and sometimes improve gut function and body metabolism, and thus can also improve health status. 
The number of lectins found in various parts of plants has now become extensive and in order to bring the reader up-to-date Table 1 [17-92] contains an overview of lectins in vegetables, fruits, cereals, seeds and nuts, and herbs and spices. As we can see more than 100 dietary vegetables contain lectins and the number of fruits is over 55. The Heath Authorities in Western society have advised its members to adopt the principle of " 5 a day", that is one should include in the daily diet five portions of vegetables, fruits, cereals and nuts etc., amounting to about $400 \mathrm{~g}$ per day [3]. In Greece, Italy, Spain and Turkey where the Mediterranean diet is used then the risk of suffering from heart disease is reduced. It is thus evident that to ensure long-term good health the diet needs to have an adequate content of plant lectins.

\begin{tabular}{|c|c|c|c|}
\hline Vegetables & & & \\
\hline Adzuki bean & Vigna angularis & {$[17]$} & Grant et al (1983) \\
\hline Alfalfa & Medicago sativum & {$[18]$} & Zhang et al (2008) \\
\hline Alpine split pea & Phaseolus sativum & {$[19]$} & Boyd \& Reguera (1949) \\
\hline Angled luffa & Luffa acutangula & {$[20]$} & Srinivas Naik et al (2014) \\
\hline Asparagus & Asparagus officinalis & {$[21]$} & Hossaini (1968) \\
\hline Asparagus pea & Lotus tetragonolobus $-L$ & {$[22]$} & Yariv et al (1967) \\
\hline Beet & Beta vulgaris & {$[18]$} & Zhang et al (2008) \\
\hline Black turtle bean & Phaseolus vulgaris var & {$[23]$} & Shudong He et al (2015) \\
\hline Blackeyed pea & Vigna sinensis & {$[17]$} & Grant et al (1983) \\
\hline Brazilian Jack Bean & Canavalia brasilienssiensis & {$[14]$} & González de Mejía \& Prisecaru (2005) \\
\hline Brittle wax bush bean & Phaseolus vulgaris, var. humilis & [19] & Boyd \& Reguera (1949) \\
\hline Broad bean & Vicia faba & {$[14]$} & González de Mejía \& Prisecaru (2005) \\
\hline Brussel sprouts & Brassica oleracea & {$[24]$} & Huang Deqi et al (1992) \\
\hline Butter bean & Phaseolus limensis & {$[19]$} & Boyd \& Reguera (1949) \\
\hline Cargen cress & Lepidium sativum & {$[18]$} & Zhang et al (2008) \\
\hline Carrot & Daucus carota & {$[25]$} & Su \& Tung (1989) \\
\hline Cauliflower & Brassica oleracea var botrytis & {$[20]$} & Srinivas Naik et al (2014) \\
\hline Celery & Apium graveolens & {$[21]$} & Hossaini (1968) \\
\hline Ceylon spinach & Basella rubra & [22] & Srinivas Naik et al (2014) \\
\hline Celery & Apium graveolens & {$[26]$} & Davidsen \& Stewart (2004) \\
\hline Chickpea & Cicer arietinum & [19] & Boyd \& Reguera (1949) \\
\hline Chilli & Capsicum аппиит & {$[25]$} & Su \& Tung (1989) \\
\hline Chinese cabbage & Brassica rapa & {$[25]$} & Su \& Tung (1989) \\
\hline Chinese chive & Allium tuberosum & [27] & Oii et al (2002) \\
\hline Chinese spinach & Amaranthus tricolor & [19] & Boyd \& Reguera (1949) \\
\hline Climbing French bean & Phaseolus vulgaris $s p$. & {$[14]$} & González de Mejía \& Prisecaru (2005) \\
\hline Cluster bean & Cyamopsis tetragonoloba & {$[20]$} & Srinivas Naik et al (2014) \\
\hline Cowpea & Vigna unguiculata & [28] & Roberson \& Strength (1983) \\
\hline Crow garlic & Allium vineale & [29] & Van Damme et al (1991) \\
\hline Cucumber & Cuccumis sativus & {$[30]$} & Allen (1979) \\
\hline Dwarf bean & Phaseolus vulgaris, var. & {$[19]$} & Boyd \& Reguera (1949) \\
\hline Dwarf flowering onions & Allium moly & [29] & Van Damme et al (1991) \\
\hline Dwarf sugar peas & Pisum sativum, var. humile & [19] & Boyd \& Reguera (1949) \\
\hline Early Alaska peas & Pisum sativum, var. humile & [19] & Boyd \& Reguera (1949) \\
\hline Edible mushroom & Agaricus bisporus & {$[14]$} & González de Mejía \& Prisecaru (2005) \\
\hline Fava bean & Vicia faba & {$[31]$} & Hemperly et al (1979) \\
\hline Field bean & Dolichos lablab & {$[32]$} & Manage et al (1972) \\
\hline
\end{tabular}




\begin{tabular}{|c|c|c|c|}
\hline Field mushroom & Agaricus campestris & [19] & Boyd \& Reguera (1949) \\
\hline French bean & Phaseolus vulgaris sp. & [19] & Boyd \& Reguera (1949) \\
\hline Garden pea & Pisum sativum $L$. & [17] & Grant et al (1983) \\
\hline Garlic & Allium sativum $L$. & {$[25]$} & Su \& Tung (1989) \\
\hline Grass pea & Lathyrus sativa & {$[33]$} & Purkait \& Koley (2019) \\
\hline Green pea & Phaseolus sativum & {$[10]$} & Nachbar \& Oppenheim (1980) \\
\hline Horse gram bean & Macrotyloma uniflorum & [20] & Srinivas Naik et al (2014) \\
\hline Hyacinth bean & Lab-lab purpureus & {$[20]$} & Srinivas Naik et al (2014) \\
\hline Jack bean & Canavalia ensiformis & {$[10]$} & Nachbar \& Oppenheim (1980) \\
\hline Jap. red sword bean & Canavalia gladiata & [35] & Une et al (2018) \\
\hline Jerusalem artichoke & Helianthus tuberosus $L$. & {$[14]$} & González de Mejía \& Prisecaru (2005) \\
\hline Kidney bean & Phaseolus vulgaris $L$. & {$[14]$} & González de Mejía \& Prisecaru (2005) \\
\hline Knife bean & Canavalia gladiata & [36] & Wong \& Ng (2005) \\
\hline Lablab bean & Dolichos lablab & [19] & Boyd \& Reguera (1949) \\
\hline Laxtons progress (pea) & Pisum sativum var. humile & [19] & Boyd \& Reguera (1949) \\
\hline Leaf beat/chard & Beta vulgaris ssp. cicla & {$[26]$} & Davidsen \& Stewart (2004) \\
\hline Leek & Allium porrum & [29] & Van Damme et al (1991) \\
\hline Lentil & Lens esculenta & {$[14]$} & González de Mejía \& Prisecaru (2005) \\
\hline Lima bean & Phaseolus coccineus & [19] & Boyd \& Reguera (1949) \\
\hline Lima bean-Alpine & P. limensis & {$[14]$} & Boyd \& Reguera (1949) \\
\hline Lentil & Lens culinaris & [14] & González de Mejía \& Prisecaru (2005) \\
\hline Lentil sprouts & Lens esculenta & {$[10]$} & Nachbar \& Oppenheim (1980) \\
\hline Lettuce & Lactuca sativa & {$[25]$} & Su \& Tung (1989) \\
\hline Lima bean & Phaseolus lunatus & {$[33]$} & Purkait \& Koley (2019) \\
\hline Lupin beans & Lupinus hybridus & [37] & Renkonen (1948) \\
\hline Marrow & Curcubita pepa & [30] & Allen (1979) \\
\hline Mat/moth bean & Vigna aconitifolia & {$[33]$} & Purkait \& Koley (2019) \\
\hline Mung bean & Phaseolus mungo & [17] & Grant et al (1983) \\
\hline Mung bean sprouts & Phaseolus mungo & {$[38]$} & Hankins \& Shannon (1978) \\
\hline Narrowleaf lupin beans & Lupinus angustfolius & [37] & Renkonen (1948) \\
\hline Navy (white) bean & Vigna radiata & [37] & Renkonen (1948) \\
\hline Okra & Abelmoschus esculentus & [39] & Guruvayoorappan et al (2015) \\
\hline Onion & Allium сера & {$[25]$} & Su \& Tung (1989) \\
\hline Parsley & Petrosecinum hortense & {$[18]$} & Zhang et al (2008) \\
\hline Pea beans & Phaseolus sp. & [19] & Boyd \& Reguera (1949) \\
\hline Pigeon pea & Cajanus cajan & [17] & Grant et al (1983) \\
\hline Pinto bean & Phaseolus vulgariss sp. & [19] & Boyd \& Reguera (1949) \\
\hline Pole bean & Phaseolus vulgaris sp. & [19] & Boyd \& Reguera (1949) \\
\hline Potato & Solanum tuberosum & {$[10]$} & Nachbar \& Oppenheim (1980] \\
\hline Prickly lettuce & Lactuca sasole & [87] & Yen et al (1980] \\
\hline Profi pea & Pisum arvense & {$[14]$} & González de Mejía \& Prisecaru (2005) \\
\hline Radish & Raphanus sativus & {$[40]$} & Tsumuraya et al (1988) \\
\hline Ramsons & Allium ursinum & [29] & Van Damme et al (1991) \\
\hline Runner bean & Phaseolus coccineus & [19] & Boyd \& Reguera (1949) \\
\hline Rutabaga/swede & Brassica napobrassica & [21] & Hossaini (1968) \\
\hline Scarlet gourd & Coccinia indica & [41] & Sanadi \& Surolia (1994) \\
\hline Shallot & Allium ascalonicum & [29] & Van Damme et al (1991) \\
\hline
\end{tabular}




\begin{tabular}{|c|c|c|c|}
\hline Siberian pea tree & Caragana arborescens & {$[42]$} & Doyle et al (1982) \\
\hline Snap pea & Pisum sativum var. macrocarpon & [39] & Guruvayoorappan et al (2015) \\
\hline Soybean & Glycine max & {$[14]$} & González de Mejía \& Prisecaru (2005) \\
\hline Soy bean sprouts & Glycine Max & {$[10]$} & Nachbar \& Oppenheim (1980) \\
\hline Speckled bean & Phaseolus sp. & [19] & Boyd \& Reguera (1949) \\
\hline Spinach & Spinacia oleracea & {$[20]$} & Srinivas Naik et al (2014) \\
\hline Spiny gourd & Momordica dioica & {$[43]$} & Dimple et al (2018) \\
\hline String bean & Phaseolus vulgaris & {$[10]$} & Nachbar \& Oppenheim (1980) \\
\hline Sutton's runner bean & Phaseolus coccineus & [19] & Boyd \& Reguera (1949) \\
\hline Sweet pepper/paprika & Capsicum annum & [43] & Krüppe (1956). \\
\hline Sweet pea & Lathyrus odoratus & {$[44]$} & Kolberg \& Sletten (1978) \\
\hline Sweet potato & Ipomoea batatus & [20] & Srinivas Naik et al (2014) \\
\hline Swiss chard & Beta vulgaris & {$[46]$} & Gold \& Balding (1975) \\
\hline Taro & Colocasisa esculenta & {$[47]$} & Pereira et al (2014) \\
\hline Tepary bean & Phaseolus acutifolius & {$[48]$} & Ferriz-Martinez et al (2015) \\
\hline Tonka beans & Dipteryx odorata & [37] & Renkonen (1948) \\
\hline Tomato & Lycopersicon esculentum & {$[10]$} & Nachbar \& Oppenheim (1980) \\
\hline Turnip/beet & Brassica campestris rapa & {$[21]$} & Hossaini (1968) \\
\hline Wax pod bush bean & P.vulgaris, var. humilis & [19] & Boyd \& Reguera (1949) \\
\hline Wild celery & Angelica archangelica & {$[2]$} & Van Damme et al (1997) \\
\hline Wild soybean & Glycine soja & [37] & Renkonen (1948) \\
\hline Winged bean & Psophocarpus tetragonobolus & [37] & Renkonen (1948) \\
\hline Vegetable marrow & Curcubita pepo & [30] & Allen (1979) \\
\hline Zucchini & Curcubita peppo & [30] & Allen (1979) \\
\hline \multicolumn{4}{|l|}{ Fruits } \\
\hline American plum & Prunus americana & [19] & Boyd \& Reguera (1949) \\
\hline Apple & Malus domesticus & [25] & Su \& Tungl (1989) \\
\hline Apricot & Prunus armeniaca & {$[20]$} & Srinivas Naik et al (2014) \\
\hline Artocarpus & Artocarpus tonkinensis & [49] & Blasco et al (1996) \\
\hline Banana & Musa acuminata $L$. & [25] & Su \& Tung (1989) \\
\hline Banana & Musa paradisiac & [50] & Koshte et al (1990) \\
\hline Bitter melon & Momordica charantia & {$[20]$} & Srinivas Naik et al (2014) \\
\hline Blackberry & Rubus fructicosus & {$[51]$} & Liénart et al (1991) \\
\hline Breadfruit & Artocorpus altilis & {$[52]$} & Pineau et al (1990) \\
\hline Camaratu bean & Cratylia mollis & [53] & Souza et al (2001) \\
\hline Cantaloupe & Cuccumis melo cantalupensis & {$[18]$} & Zhang et al (2008) \\
\hline Cempedak & Artocorpus champeden & [49] & Blasco et al (1996) \\
\hline Chempedak & Artocorpus integer & [49] & Blasco et al (1996) \\
\hline Cherry & Prunus avium bigarreaus & {$[18]$} & Zhang et al (2008) \\
\hline Currant & Ribes rubrum & [18] & Zhang et al (2008) \\
\hline Date & Phoenix dactylifera & {$[20]$} & Srinivas Naik et al (2014) \\
\hline Elderberry & Sambucus nigra & [14] & González de Mejía \& Prisecaru (2005) \\
\hline Ginger & Zingibar offinicinale & [25] & Su \& Tung (1989) \\
\hline Grape & Vitis vinifera & {$[20]$} & Srinivas Naik et al (2014) \\
\hline Grapefruit & Citrus medica & {$[18]$} & Zhang et al (2008) \\
\hline Ground elder & Aegopodium podagraria & {$[6]$} & Peumans \& Van Damme (1985) \\
\hline Guava & Psidium guava & {$[54]$} & Bhat et al (2018) \\
\hline
\end{tabular}




\begin{tabular}{|c|c|c|c|}
\hline Jackfruit & Artocarpus integrifolia & {$[55]$} & Kabir \& Daar (1994) \\
\hline Jambolan & Syzgium jambolanum & {$[20]$} & Srinivas Naik et al (2014) \\
\hline Japanese red elder & Sambucus sieboldiana & [56] & Tazaki \& Shibuya (1989) \\
\hline Jujube red date & Zizyphus jujuba & {$[20]$} & Srinivas Naik et al (2014) \\
\hline Kiwi & Actinidia deliciosa & {$[25]$} & Su \& Tung (1989) \\
\hline Lemon & Citrus medica & [25] & Su \& Tung (1989) \\
\hline Lime & Citrus aurantifolia & [57] & Helleland \& Pryme (2012) \\
\hline Malabar plum & Syzgium cumnii & {$[20]$} & Srinivas Naik et al (2014) \\
\hline Mango & Mangifera indica & {$[20]$} & Srinivas Naik et al (2014) \\
\hline Melon & Curumis melo & [25] & Su \& Tung (1989) \\
\hline Monkey fruit & Artocarpus lacucha & {$[58]$} & Chowdhury et al (1987) \\
\hline Mulberry & Morus alba $L$. & [59] & Yeasmin et al (2001) \\
\hline Mungbean sprouts & Phaseolus mungum & {$[18]$} & Zhang et al (2008) \\
\hline Orange & Citrus sinensis & [25] & Su \& Tung (1989) \\
\hline Papaya & Carica papaya & {$[60]$} & Wang et al (2011) \\
\hline Passion fruit & Passiflora edulis & [25] & Su \& Tung (1989) \\
\hline Plum & Prunus domestica & {$[20]$} & Srinivas Naik et al (2014) \\
\hline Peacock ginger & Kaempferia rotunda & [61] & Kabir \& Reza (2014) \\
\hline Pineapple & Ananas comosus & {$[25]$} & Su \& Tung (1989) \\
\hline Pitanga & Eugenia uniflora & {$[62]$} & Oliveira et al (2008) \\
\hline Plum & Spontia vulgaris & {$[25]$} & Su \& Tung (1989) \\
\hline Pomegranate & Punica granatum & {$[18]$} & Zhang et al (2008) \\
\hline Pomerans & Citrus aurantium & {$[44]$} & Kruppe (1956) \\
\hline Pumpkin & Curcubita maxima & [63] & Smith et al (1987) \\
\hline Quince & Cydonia vulgaris & [64] & Coutino-Rodriguez et al (2001) \\
\hline Raspberry & Rubrus idaeus & {$[18]$} & Zhang et al (2008) \\
\hline Rhubarb & Rheum rhapontium & {$[18]$} & Zhang et al (2008) \\
\hline Snake gourd & Trichosanthes cucumerina anguina & {$[20]$} & Srinivas Naik et al (2014) \\
\hline Squash & Curcubita maxima & {$[20]$} & Srinivas Naik et al (2014) \\
\hline Strawberry & Fragaria vesca & {$[18]$} & Zhang et al (2008) \\
\hline Sugar beet & Beta vulgaris ssp. saccharifera & [65] & Vyskrebentseva \& Borisova (1966) \\
\hline Summer grape & Vitis aestivalis & [19] & Boyd \& Reguera (1949) \\
\hline Tamarind & Tamarindus indica & {$[54]$} & Bhat et al (2018) \\
\hline Tejocote & Crataegus mexicanus & [54] & Bhat et al (2018) \\
\hline Water melon & Citrullus vulgaris & {$[18]$} & Zhang et al (2008) \\
\hline Wheat germ & Secale cereale & {$[66]$} & Peumans et al (1982) \\
\hline White mulberry & Morus alba & {$[20]$} & Srinivas Naik et al (2014) \\
\hline Zucchini & Cucubrita pepo & [18] & Zhang et al (2008) \\
\hline \multicolumn{4}{|l|}{ Cereals } \\
\hline Barley & Hordeum vulgare & [33] & Purkait \& Koley (2019) \\
\hline Corn/Maize & Zea mays & [67] & Markov \& Khavkin (1982) \\
\hline Oats & Avena sativa & {$[68]$} & Langston-Unkefer \& Gade (1984) \\
\hline Rice & Oryza sativa $L$. & {$[18]$} & Zhang et al (2008) \\
\hline Rye & Secale cereale & [66] & Peumans et al (1982) \\
\hline Sorghum & Sorghum bicolor & {$[33]$} & Purkait \& Koley (2019) \\
\hline Triticale & Triticale spp. & [69] & Hariharan \& Rao (1978) \\
\hline Wheat & Triticum aestivum $L$. & {$[14]$} & González de Mejía \& Prisecaru (2005) \\
\hline
\end{tabular}




\begin{tabular}{|c|c|c|c|}
\hline Wheat germ & Tritium vulgaris & [70] & Hamid \& Masood (2009) \\
\hline \multicolumn{4}{|l|}{ Seeds and nuts } \\
\hline Amaranth & Amaranthus caudatus & [19] & Boyd \& Reguera (1949) \\
\hline Baru almonds & Dipteryx alata Vog. & [71] & Fraguas et al (2014) \\
\hline Caraway seeds & Carum carvi & {$[18]$} & Zhang et al (2008) \\
\hline Caraway & Trachyspermum ammi & [33] & Purkait \& Koley (2019) \\
\hline Coconut & Cocus nucifera & [18] & Zhang et al (2008) \\
\hline Coral vine & Antigonon leptopus & [2] & Van Damme et al (1997) \\
\hline Griffonia seeds & Griffonia simplicifolia & [14] & González de Mejía \& Prisecaru (2005) \\
\hline Hazelnut & Corylus avelania & {$[70]$} & Hamid \& Masood (2009) \\
\hline Hog-peanut & Amphicarpaea bracteata & {$[42]$} & Doyle et al (1982) \\
\hline Lebbeck & Albizia lebbeck & {$[72]$} & Adamude et al (2020) \\
\hline Mimosa tree seeds & Albizzia julibrissin & {$[42]$} & Doyle et al (1982) \\
\hline Okra & Abelmoschus esculentus & [73] & Soares et al (2012) \\
\hline Peanut/ground nut & Arachis hypogea & [74] & Lotan et al (1975) \\
\hline Pinhao & Aurocaria brasiliensis & [75] & Datta et al (1991) \\
\hline Pistacio nut & Pistacia vera & {$[20]$} & Srinivas Naik et al (2014) \\
\hline Red lucky seed & Adenanthera pavonina & [76] & Prakashkumar et al (1997) \\
\hline Sesame seeds & Sesamum indicum & [33] & Purkait \& Koley (2019) \\
\hline Solomons seeds & Polygonatum cyrtonema & [77] & Liu et al (2009) \\
\hline Sunflower seeds & Halianthus annus & {$[18]$} & Zhang et al (2008) \\
\hline Walnut & Juglans regia & {$[18]$} & Zhang et al (2008) \\
\hline \multicolumn{4}{|c|}{ Flowers, herbs and spices } \\
\hline Alisma & Alisma orientalis & [79] & Shao et al (2011] \\
\hline Allspice & Pimenta officinalis & [18] & Zhang et al (2008) \\
\hline Amaryllis & Hippeastrum hybrid & [78] & Sharma et al (1996) \\
\hline Arum & Arum maculatum & [78] & Sharma et al (1996) \\
\hline Astragalus & Astragalus mongholicus & {$[80]$} & Yan et al (2005) \\
\hline Black mustard & Brassica niagra & [33] & Purkait \& Foley (2019) \\
\hline Black pepper & Piper nigrum & [20] & Srinivas Naik et al (2014) \\
\hline Black tumeric & Curcuma amarissima Roscoe & {$[82]$} & Kheeree et al (2010) \\
\hline Camels foot tree & Bauhinia purpurea & [42] & Doyle et al (1982) \\
\hline Candelabra aloe & Aloe arborescens & {$[42]$} & Doyle et al (1982) \\
\hline Celandine & Chelidonium majus & {$[14]$} & González de Mejía \& Prisecaru (2005) \\
\hline Chicory & Chichorium intybus & {$[46]$} & Gold \& Balding (1975) \\
\hline Cocoa & Theobromo cacao & {$[18]$} & Zhang et al (2008) \\
\hline Coffee & Coffea arabica & [18] & Zhang et al (2008) \\
\hline Common broom & Sarothamnus scoparius & [84] & Gurtler (1978) \\
\hline Coriander & Corandrum sativum & [33] & Purkait \& Koley (2019) \\
\hline Desert false indigo & Amorpha fruticose & [19] & Boyd \& Reguera (1949) \\
\hline Fenugreek & Trigonella coerulea & [37] & Renkonen (1949) \\
\hline Flame-of-the-forest & Butea monosperma & {$[76]$} & Prakashkumar et al (1997) \\
\hline Gorse & Ulex europaeus & [86] & Horejsi \& Kocourek (1974) \\
\hline Greater celendine & Chelidonium majus & {$[78]$} & Sharma et al (1996) \\
\hline Indian cress & Tropaeolum majus & [19] & Boyd \& Reguera (1949) \\
\hline Jack-in-the-pulpit & Arisaema tryphyllum & {$[88]$} & Boyd et al (1961) \\
\hline
\end{tabular}




\begin{tabular}{|c|c|c|c|}
\hline Japanese pagoda & Styphnolobum japonicum & {$[90]$} & Hankins et al (1988) \\
\hline Marjoram & Labiacae organum & {$[18]$} & Zhang et al (2008) \\
\hline Mistletoe & Viscum album & [89] & Franz et al (1981) \\
\hline Nutmeg & Myristica fragrans & {$[70]$} & Hamid \& Masood (2009) \\
\hline Peppermint & Menta piperita & [70] & Hamid \& Masood (2009) \\
\hline Plantain & Musa sp. & {$[14]$} & González de Mejía \& Prisecaru (2005) \\
\hline Rattlepods & Crotolaria sp. & [35] & Khanne \& Sehajpal (1980) \\
\hline Red clover & Trifolium pratense & [37] & Renkonen (1948) \\
\hline Sapota & Achras zapota & {$[20]$} & Srinivas Naik et al (2014) \\
\hline Scorpion's tails & Scorpiurus vermiculatus & [37] & Renkonen (1948) \\
\hline Sickle senna & Cassia tora & [91] & Grant et al (1991) \\
\hline Snakes beard & Ophiopogon japonicus & [92] & Liu et al (2009) \\
\hline Snapdragon & Antirrhinum majus & {$[2]$} & Van Damme et al (1971) \\
\hline Snowdrop & Galanthus nivalis & [78] & Sharma et al (1996) \\
\hline Sow thistle & Sonchus oleraceaus & [35] & Khanne \& Sehajpal (1980) \\
\hline Stinging nettle & Urtica dioica & [14] & González de Mejía \& Prisecaru (2005) \\
\hline Tian ma & Gastrodia elata & [92] & Liu et al (2002) \\
\hline Tea & Hibiscus rosa sinensis & [35] & Khanne \& Sehajpal (1980] \\
\hline Turmeric & Curcuma domestica & {$[20]$} & Srinivas Naik et al (2014) \\
\hline White/black tea & Camellia sinensis & [20] & Srinivas Naik et al (2014) \\
\hline Yellow sweet clover & Melilotus indicus & [37] & Renkonen (1948) \\
\hline Yellow bauhinia & Bauhinia tomentosa & [37] & Renkonen (1948) \\
\hline
\end{tabular}

National campaigns encouraging people to eat " 5 a day", have not been particularly successful. In Scotland, for example, daily consumption between 1993 and 2000 only increased from 190g to $200 \mathrm{~g}$. Since there is considerable evidence that consumption of sufficient amounts of fruit and vegetables has an impact on preventing many chronic diseases (heart disease, stroke, several forms of cancer, for example [93], these results are certainly disheartening.

\section{What Happens to Dietary Lectins?}

Sharma et al [78] demonstrated that a series of plant lectins can bind to receptors on the surfaces of human intestinal cells (biopsy material). Following binding to appropriate receptors, lectins can then propagate release of intracellular second messenger molecules. Although lectin binding is most extensive in the small intestine, binding can occur throughout the entire GIT from the oral cavity to the distal colon. Lectin-binding studies on human small intestine biopsy material, showed that a series of plant lectins can bind to receptors on the surfaces of different types of cells found in Peyer's patches [78]. From Aricigil and Pryme [12] (see Table 1.3) we see that the overall frequency of binding of 27 selected lectins to Follicle-associated epithelium (FAE), Villus epithelium (VE) and Gut-associated lymphoid tissue (GALT) was $59 \%, 70 \%$ and $44 \%$, respectively. It is thus evident that the three areas bind lectins to various degrees. The different cell types in the three areas of Peyer 's patches also demonstrate varying levels of binding specificity. For example, in GALT lymphocytes only bound $11 \%$ of the lectins while macrophages bound $41 \%$. A further level of specificity is illustrated by the fact that in FAE only 5 of the 27 lectins were shown to bind to all cell types, in VE 4/27 and in GALT only two lectins were seen to bind to both lymphocytes and macrophages. These observations illustrate the complex pattern of binding of lectins to the various cell types found in Peyers patches.

The complexity of binding is further illustrated by the results shown by Sharma et al [78]. Three lectins all with the same binding specificity for D-GalNac exhibit different staining patterns in binding studies performed on different cell types in three areas of human Peyers patches. The Bryonia dioica (BDA) lectin has a very high affinity for binding to macrophages in GALT. ML binds strongly to M-cells and enterocytes of FAE while SNA binds with high intensity to goblet cells of VE and macrophages in GALT. The biological significance of these observations is currently unknown, though it is tempting to speculate, that lectins that have the property of binding to different cell types associated with welldefined areas of Peyers patches will initiate separate, and perhaps specific biological responses. 
Etzler and Branstrator [94] studied sections of small intestine from adult male rats. These were examined by fluorescence microscopy after treatment with fluorescein isothiocyanatelabeled lectins from Dolichos biflorus, Lotus tetragonolobus, Ricinus communis, and Triticum vulgare (wheat germ). The latter three lectins reacted with the microvillar portion of the epithelial cells lining the crypts and villi in sections of intestine adjacent to the pylorus. This pattern of reactivity was sharply altered along the first $15 \mathrm{~cm}$ of intestine so that in sections distal to this point the luminal surfaces of only those epithelial cells in the crypts and at the base of the villi reacted with the $\mathrm{L}$. tetragonolobus and $\mathrm{R}$. communis lectins, whereas the wheat germ lectin reacted with the surfaces of cells lining the villi. In sections from the distal end of the small intestine, all three lectins reacted with the surfaces of cells only at the base of the villi and in the crypts.

These results show a difference in surface components in cells at various portions on the villi, and the dependence of these differences on the region of intestine. The D. biflorus lectin reacted with approximately $25 \%$ of the goblet cells at each level of intestine studied. Whereas the reactivities of the goblet cells with the other three lectins were dependent upon the region of intestine.

Most lectins, in line with all other proteins, are inactivated under conditions that lead to irreversible protein denaturation, for example heat, and thereby lose their biological activity. However, different plant lectins exhibit varying levels of heat stability, such that many, but not all, are inactivated as a result of cooking, frying, grilling etc. Raw vegetables though, and fruit and nuts, will thus have a high content of biologically active lectins.

This unique group of proteins have potent biological activity following their ingestion. Several lectins, for example, have been found to possess anticancer properties both in vitro, in vivo, and in human case studies [95-100]. Some lectins can preferentially bind to cancer cell membranes or their receptors, causing cytotoxicity upon internalization and activation, resulting in apoptosis and cessation of tumour growth [101-102].

Lectins are able to modify the cell cycle by inducing nonapoptotic G1-phase accumulation mechanisms, G2/M phase cell cycle arrest and apoptosis, and can activate the caspase cascade. They can also down-regulate telomerase activity and result in an inhibition of angiogenesis [101]. Ingestion of specific lectins can lead to a sequestration of the available body pool of polyamines, resulting in reduced cancer cell growth. Many lectins have been shown to stimulate the immune system by altering the production of various interleukins. This may indeed be an extremely important property of the dietary lectins since they are able to prime the immune system, thus keeping it activated.
It would seem likely that NK cells have a similar role in the immunologic surveillance against cancer in humans and that plant lectins here play a vital role [102]. There is, therefore, a strong indication of the importance of keeping the number of activated NK cells in the blood within normal limits.

Many lectins taken orally are resistant to low $\mathrm{pH}$ and proteolytic breakdown due to their carbohydrate shell and complex structure. They thus remain fully active during their passage through the entire alimentary canal [103]. The surface of the mammalian gut is highly glycosylated, and the epithelium is covered by glycolipids and glycoproteins. Through their saccharide binding, lectins bind to epithelial membrane glycoproteins, including receptors of hormones, growth factors and cytokines, transport proteins and brush-border membrane enzymes, glycolipids, gangliosides and secreted mucins $[103,104]$. Although lectin binding is most extensive in the small intestine, similar binding does occur throughout the entire digestive system from the oral cavity to the distal colon. The lectin can send messages into the cell via second messengers or by the lectin itself entering the cell by endocytosis.

The major effects mediated by lectin binding in the digestive tract are: (a) hyperplasia, increase in crypt cell production rate (b) overstimulation of secretory cells and exhaustion of their secretory capacity, (c) replacement of appropriate endogenous ligands bound to their receptors, and (d) immune stimulation. Both (a) hyperplasia and (d) immune stimulation are indeed today interesting aspects in cancer research.

Some plant lectins have a high level of glycosylation and others are characterised by having a very tight globular structure. These molecules can therefore be extremely resistant to digestive processes and are therefore not completely degraded following exposure to acid and proteolytic enzymes in the GIT. Their biological activity thus being to a large extent retained during intestinal passage. For example, $>90 \%$ of phytohaemagglutinin (PHA) and $>60$ of Sambucus nigra (SNA) lectins in kidney bean and elderberry, respectively, were recovered in an active form [105]. Very many lectins can thus remain fully biologically and immunogenically active during their passage through the entire alimentary canal [78]. Those lectins that survive will thus be able to bind to cells present in the intestine that bear appropriate receptors [2,105]. The mammalian gut surface is highly glycosylated and the epithelium is covered by numerous glycolipids and glycoproteins. Because of their affinity for saccharides, lectins bind to epithelial membrane glycoproteins, including receptors for hormones, growth factors and cytokines, transport proteins and brush-border membrane enzymes, glycolipids, gangliosides and secreted mucins [78].

As seen in Aricigil and Pryme [12, see Figure 1.1] a lectin, following binding to the cell surface, can send information into the 
cell's interior via second messengers and instigate an intracellular response. This is often manifested in the form of a modulation of gene expression and it has been envisaged that biologically active molecules such as cytokines, growth factors, hormones or enzymes may be produced, as suggested by Bardocz et al [105]. These molecules may be released from the cell and then result in a systemic effect. On the other hand active products may be transported to neighbouring cells inducing some form of local stimulation. A lectin, though, may enter itself the cell through endocytosis and then cause a direct intracellular effect.

The GIT, through its entire length, has various levels of glycosylation. Specific lectin binding can be therefore very different in the stomach, small intestine, and large intestine [78, 103]. Different lectins can also bind to the same cell surface and these can therefore exert a synergistic response. In Figure 1.1, Aricigil and Pryme [12], we can see that two different lectins (labeled A and B) may bind to their respective receptors on the surface of the same cell. This would of course be dependent on the two lectins being present in the intestine at the same time, thus illustrating the importance of a multicomponent diet. At the present time our knowledge concerning the possible simultaneous involvement of a number of dietary lectins in causing a positive biological response is virtually non-existent.

A lectin can either stimulate a receptor in the same manner as an endogenous ligand, or either strengthen, weaken or even inhibit the signal initiated by the primary ligand-receptor interaction. It is likely that this occurs as a result of the lectin-bound receptor complex releasing second messengers that can in turn modulate gene expression. Newly synthesised molecules are able to reach appropriate targets (extracellular or intracellular) and there induce different forms of biological response e.g. immuno-stimulation.

\section{Oral Immunogenicity}

The function of the gut associated lymphoid tissue is to absorb minute samples of oral antigens via Peyers patches M-cells and activate the gut immune system. As lectins are able to bind to M-cells [106], their endocytosis is more extensive, which makes them more powerful immunogens than other antigens. Lectins influence the immune system by evoking local and systemic immune responses and sometimes they can induce strong allergenic reactions [107109]. Mitogenic lectins are inducers of lymphocyte proliferation. Several components of the immune system, such as mast cells, basophils, eosinophils and others produce or release cytokines and chemokines when exposed to appropriate lectins.

\section{The Effect of Plant Lectins in Animal Model Sys- tems and Observations Made in Humans}

Research performed on plant lectins has been mainly performed on laboratory animals. It is likely that many of the interesting findings cannot be directly transferred to humans. This is a direct result of the conditions prevailing during the experiments; firstly, much larger doses have been administered than would be realistic for humans to consume, secondly, the method of application e.g. by intragastric intubation or subcutaneous injection, is often not at all relevant in the "normal" human situation, and thirdly, in animal experiments the effects of a single given lectin have been typically studied and this is atypical for our human lifestyle where, on a balanced diet of vegetables, fruit and nuts, a series of lectins would be ingested, often during the same meal. In Table 2 we see the approximate amounts of lectin present in common foodstuffs. It is apparent that the amounts vary considerably from the kidney bean $(<500 \mathrm{mg} / 50 \mathrm{~g})$ to the tomato $(<0.05 \mathrm{mg} / 50 \mathrm{~g})$. These values, however, are dependent on the nature of the form of preparation of the foodstuff prior to its consumption.

\begin{tabular}{|c|c|c|}
\hline Table 2: Approximate amounts of lectin in non-cooked common foods. & $<500 \mathrm{mg} / 50 \mathrm{~g}$ \\
\hline Kidney bean & Phaseolus vulgaris & $<250 \mathrm{mg} / 50 \mathrm{~g}$ \\
\hline Taro & Colocasia esculenta & $<50 \mathrm{mg} / 50 \mathrm{~g}$ \\
\hline Peanut & Arachis hypogea & $<50 \mathrm{mg} / 50 \mathrm{~g}$ \\
\hline Soybean & Glycine max & $<50 \mathrm{mg} / 50 \mathrm{~g}$ \\
\hline Jackfruit & Artocarpus integrifolia & $<50 \mathrm{mg} / 50 \mathrm{~g}$ \\
\hline Elderberry & Sambucus nigra & $<50 \mathrm{mg} / 50 \mathrm{~g}$ \\
\hline Garlic & Allium sativum L. & $<50 \mathrm{mg} / 50 \mathrm{~g}$ \\
\hline Pea & Phaseolus sp. & $<50 \mathrm{mg} / 50 \mathrm{~g}$ \\
\hline Lentil & Lens esculenta & $<50 \mathrm{mg} / 50 \mathrm{~g}$ \\
\hline Broad bean & Vicia faber & $<50 \mathrm{mg} / 50 \mathrm{~g}$ \\
\hline Amaranth & Amaranthus caudatus & $<25 \mathrm{mg} / 50 \mathrm{~g}$ \\
\hline Barley & Hordeum vulgare & $<25 \mathrm{mg} / 50 \mathrm{~g}$ \\
\hline Rice & Oryxa sativa L. & $<25 \mathrm{mg} / 50 \mathrm{~g}$ \\
\hline Rye & Secale cereal & \\
\hline
\end{tabular}




\begin{tabular}{|c|c|c|}
\hline Wheat & Triticum aestivum L. & $<25 \mathrm{mg} / 50 \mathrm{~g}$ \\
\hline Potato & Solanum tuberosum & $<0.25 \mathrm{mg} / 50 \mathrm{~g}$ \\
\hline Leek & Allium porrum & $<0.05 \mathrm{mg} / 50 \mathrm{~g}$ \\
\hline Onion & Allium cepa & $<0.05 \mathrm{mg} / 50 \mathrm{~g}$ \\
\hline Shallot & Allium ascalonicum & $<0.05 \mathrm{mg} / 50 \mathrm{~g} / 50 \mathrm{~g}$ \\
\hline Cucumber & Cuccumis sativus & $<0.05 \mathrm{mg} / 50 \mathrm{~g}$ \\
\hline Melon & $<0.05 \mathrm{mg} / 50 \mathrm{~g}$ & $<0.05 \mathrm{mg} / 50 \mathrm{~g}$ \\
\hline Pumpkin & Curcubita máxima & \\
\hline Tomato & Lycopersicon esculentum \\
\hline
\end{tabular}

If and how different lectins work together in concert is at present not known. Some combinations may be beneficial while others may not necessarily be so. In a pilot experiment (Aarra and Pryme, unpublished) showed that when lectin-rich berries and vegetables were combined in various amounts, the cytokine response in human lymphocytes changed with respect to what was seen when the plant extracts operated alone. Some responses were amplified while others were reduced. This is also the likely situation in the human body where the gut is constantly exposed to all kinds of lectins which constantly bind to receptors and mediate different responses, fine-tuned and balanced by the lectin components in the food we eat. There is still a lot of research that needs to be done to understand this area of human nutrition.

Toxic effects of lectins are based on observations related to isolated episodes. It is well known that ricin (from castor beans), a type 2-RIP, can cause death within the space of a couple of days if it injected so that it reaches the blood stream directly. Abrin and volkesein lectins are also known to be lethal toxins [2]. These, however, are present in plants that do not belong to our natural diet.

To be able to promote biological effects, lectins that are present in common foodstuffs have to be in a biologically active form and they must have the property of being able to bind to glycan receptors under the conditions that prevail in the GIT. Even though most lectins satisfy both criteria, the effects can be variable, depending on the type of lectin, its binding specificity and strength of binding $[110,111]$. The prevailing physiological conditions in the GIT (e.g $\mathrm{pH}$, level of bile salts, bacterial and yeast flora) will undoubtedly have an effect on binding effectivity and we can therefore expect great individual differences. Iliev et al [112] have in fact reported that the presence of a fungal community in the GIT (the so-called "mycobiome") that coexists with bacteria and greatly increases the repertoire of organisms that have the capacity to interact with the immune system of the intestine, thereby potentially having a major influence on health and disease. These workers have identified a polymorphism in the gene coding for Dectin-1 (a C-type lectin receptor) that is strongly associated with a severe form of ulcerative colitis.
Lectins that do not bind to the mucosa of the GIT, or are prevented from doing so, will be unable to induce biological effects through the mechanism indicated [12]. As mentioned earlier it is feasible, however, that some lectins may be taken up by endocytosis, are thus internalised and thereby will be in a position to promote a biological response. Such a response, however, will depend on how quickly the body is able to produce an antibody [113].

An experiment with rats given parenteral nutrition, to establish whether or not PHA and peanut Arachis hypogea lectin (PNA) could reverse GIT and pancreas atrophy was performed by Jordinson et al [114]. During a period of 4 days the rats received a continuous infusion of parenteral nutrition, and the test group a daily dose of lectins in addition. The results showed that both these lectins could prevent gastrointestinal atrophy that arose as a result of parenteral nutrition. Interestingly, their effects in the GIT were specific in that PHA had greatest effect on the fundus mucosa in the ventricle and upper region of the small intestine, while PNA was most effective in the large bowel. The observed effects of these lectins were partly attributed to direct binding of the lectin to the surface membrane and partly to a local lectin-mediated liberation of growth stimulating hormones, which in turn results in an increased synthesis and uptake of polyamines. This is an interesting example where two lectins from different sources were able to act positively in concert.

That plant lectins can modify the natural composition of the microflora in the intestine has been demonstrated by directly allowing these molecules to interact with lectins and agglutinating substances. It was seen that particular bacterial species in the intestinal lumen, could result in their selective elimination. Freed [115] has shown that lectins can prevent the binding of bacteria to the brush border membrane surface by increased cell proliferation, a modification of the level of glycosylation or by occupying binding sites for bacteria.

Banwell et al [116] performed an experiment where 2 groups of rats, one being bacteria-free, were fed a PHA-containing diet for 7 days and the intestinal flora was then checked. In contrast to rats maintained under bacteria-free conditions, "normal" rats 
showed an overgrowth of Escherichia coli (E. coli). This experiment demonstrated that lectins can effectively modify the microflora of the intestine.

The oral feeding of PHA over time caused the normally thin and continuous mucous layer in the intestine to become thicker and uneven. Certain areas may thus lose their protection. This can theoretically lead to a weakening of the protective role that the mucous barrier plays in the intestine [115].

In parallel with the effects observed in the small intestine in rats, PHA in the diet also causes hypertrophy of the pancreas and promotes an increased secretion of digestive enzymes as a result of increased cholecystokinin (CCK) production [116-118]. This is a peptide hormone produced and released by I-cells, a type of glandular cell found in the wall of the duodenum. The hormone cholecystokinin (CCK) has several properties including a role in secretion of pancreatic enzymes, regulation of food intake, delay of emptying the ventricle and stimulation of contraction of the gall bladder.

Pusztai et al [118] have expressed the opinion that low doses of PHA can probably be useful as a therapeutic agent for patients with chronic pancreatitis since PHA is able to stimulate growth of the pancreas. Vasconcelos and Oliveira [119] have shown that PHA, in a dose-dependent manner, can have an effect on the endocrine pancreas by interfering with the secretion of insulin. In rats fed PHA the plasma insulin level was seen to fall while the blood glucose concentration remained unchanged. A variety of homeostatic processes are activated in order to compensate for the low insulin level. These include changes in levels of glucagon and glucocorticoids. Reduced insulin secretion results in increased secretion of glucagon that mobilises the breakdown of fat from depots.

That PHA may be useful as a dietary supplement or a therapeutic agent in order to stimulate GIT function, and in the treatment of obesity, has been suggested by Pusztai et al. [118]. First, however, it will be necessary to provide safe and effective doses in clinical trials.

It was shown by Kordas et al [120] that PHA has the property of binding to the gastric mucosa, and to parietal cells in the ventricle. The interaction resulted in a reduction in both endogenously and exogenously stimulated acid secretion. This has been been associated with delayed emptying of the ventricle [119]. It has been suggested that certain plant lectins, for example those present in Allium species, may have promising probiotic effects.

The presence of lectins in elderberry fruit is well known [121] and the concentration is about $10 \mathrm{mg} / \mathrm{kg}$ raw fruit. Of the three elderberry lectins in the fruit there is most of the SNA-IVf type while there are decreasing amounts of SNA-1f and SNA-Vf [see
Pryme and Dale [122] Table 8.4). Interestingly, Jiménez et al [123]) have shown that elderberry lectins are refractory to proteolysis caused by gastric or duodenal fluids. Lectin-containing elderberry preparations have been successfully used by a number of authors for the relief of gastrointestinal ailments (e.g. [122,124-126]).

\section{Systemic Effects}

A systemic effect can be caused by biologically active lectins. This can be caused either by simulating the effects of endocrine hormones or they can bind to neuroendocrine cells in the GIT. This can lead to secretion of peptide hormones, which in turn can modulate the endocrine system [2].

Of the five main groups of heat shock proteins (HSP), the $70 \mathrm{kDa}$ family is the best studied. This protein is central in cancer since it suppresses apoptosis by inhibiting the caspase chain reaction [127] and thus has the function of a survival protein. It can also enter into a strong complex with mutated tumour suppressor protein p53 [128], and effectively obstructs it from entering the nucleus where it activates transcription.

A malignant tumour can be regarded as a tumour where, following a process of selection, cells have lost the ability to commit suicide (i.e., enter apoptosis) [129]. Over-expression of HSP70 has thus been observed in malignant tumours of diverse origin and increased levels are known to be associated with poor prognosis in cancer [130-132]. Rohde et al [132] have shown that if HSP70 is eliminated from a cell then apoptosis is spontaneously induced. Inhibition of HSP70 synthesis would therefore appear to be a novel and promising approach for treatment of human cancers, including those that show resistance to standard forms of therapy [133].

Pryme et al [100] have demonstrated that PHA, when added to the diet of mice, results in a great reduction in HSP70 levels in NHL cells growing intraperitoneally in mice. Briefly, two groups of mice were injected intraperitoneally with NHL cells; one group was maintained on a lectin-free diet while the second group was fed a diet containing PHA (7mg/g diet). On days 2, 3, 4 and 7 after injection mice were sacrificed and the peritoneal cavity was washed extensively with PBS to recover the tumour cells. Extracts were prepared from the harvested cells. Following electrophoresis and Western blotting to visualize HSP70, band intensity was determined and plotted as a function of duration of feeding PHA. The results showed that when a PHA- containing diet was fed to mice injected with NHL cells then a drastic reduction occurred in HSP70 levels in a time-dependent manner. After two days of feeding PHA the HSP70 level was already reduced by about $65 \%$. Two days later the level had decreased to $10 \%$ of that expressed in NHL cells growing in mice fed a lectin-free diet. Seven days after injection HSP70 was virtually non-detectable. 
What is striking with these observations is that the effect is seen after dietary intake of a normal plant protein. It would seem unlikely that PHA merely diffuses from the gut lumen into the intraperitoneal cavity since the molecule is a large $118 \mathrm{kDa}$ protein [134]. As described earlier (and shown in Figure 1.1, Aricigil and Pryme, [12]) it is postulated that following lectin binding a secondmessenger response evokes a stimulation of transcription and causes a subsequent release of biologically active molecules from the cells that are then able to induce a systemic response. It would appear that following entry into the bloodstream a factor is able to pass through capillary walls and into the intraperitoneal fluid thereby coming into contact with the NHL cells. Following uptake by the NHL cells transcription of the HSP70 gene would be rapidly affected, resulting in a rapid reduction in intracellular levels of the HSP70 protein. The result being reduced growth of the NHL cells. The consequences may be of extreme interest since it is evident here that a single dietary lectin is capable of inducing a response in the body that is detrimental to the growth of cancer cells.

Using a lectin-containing extract derived from Korean mistletoe Yoon et al [135] observed an anti-metastatic effect in a series of tumours where anti-angiogenic mechanisms were involved. In later experiments an induction of apoptosis was reported in tumours [136]. Similarly, using a purified lectin from Korean mistletoe, it was shown that mechanisms involving anti-angiogenesis and apoptosis were involved in reducing growth of a B16-BL6 melanoma in mice. Yoon et al [137] have described that the anti-tumour effect of the Korean mistletoe lectin can be attributed to the activation of both macrophages and NK cells. There are, therefore, a series of recent observations clearly indicating that the administration of plantderived lectins can be beneficial in reducing tumour growth [138141].

Even though mistletoe is not recognised today as a normal constituent of our diet, the plant was used widely in ancient times in folk medicine. This probably led to the development of receptors in the GIT having the property of binding mistletoe lectins. This could perhaps explain why ML-2 has been shown to bind to the FAE and VE areas in human Peyers patches (Table 1.4 in Aricigil and Pryme, [12]; [78]).

Industrially processed food forms an increasing part of everyday life. The means by which such food is prepared will often result in a loss (degradation, denaturation etc.) of biologically active molecules e.g., lectins. As mentioned above lectins can have extremely important functions and their "removal" from the diet would therefore not be desirable. A person closely following the blood type diet would probably eat lower amounts of processed food than non-followers, meaning that their diet would have a higher active lectin content. This may then afford an explanation for some of the positive effects that D'Adamo has described [142]. The positive results that people have reported may well be explained by a general improvement in life style and health attitudes such as less fat, salt, sugar, more fruit and vegetables, reduced smoking, a lower alcohol consumption, and a higher level of physical activity. It is thus quite possible that the overall effect of D'Adamo's dietary recommendations have in fact been positive by increasing public awareness of what they eat. On the other hand his warning of the potential hazards of dietary lectins would seem to be unfounded. Accumulating scientific evidence in fact clearly indicates that dietary lectins are important constituents of our diet, along with vitamins, minerals, trace elements, antioxidants and the 3 and 6-omega fatty acids.

The observations described above strongly suggest that our diet needs to contain sufficient amounts of lectins in an active form in order for them to trigger the immune system. It is unfortunate that in general modern diets provide limited amounts of active plant lectins. Although there are exceptions such as the Mediterraneantype diet. A low level of lectin intake may perhaps mean that we are unable to maintain a high-level of immuno-surveillance. This will result in that we will be more prone to infections and other disorders, for example cancer. There is thus a strong case for dietary lectin supplementation, or at least a strong recommendation to increase the content of non-cooked fresh vegetables, fruit and nuts in our diets. In addition to improved NK cell levels, increases in serum levels of endostatin, TNF $\alpha$ and $\beta$-endorphin were recorded within a few days of ingesting the lectin preparation, indicating a relatively rapid biological response to the lectins [113]. These observations from normal, healthy individuals were in line with beneficial effects reported in cases of terminal cancer [100].

In their review González De Mejía and Prisecaru [15] discuss the inhibitory effects of plant lectins on malignant cells in vitro and summarise these as follows : (1) ingestion of lectins sequesters the available body pool of polyamines, thereby thwarting cancer cell growth, (2) they affect the immune system by altering the production of various interleukins, or by activating certain protein kinases, (3) lectins can bind to ribosomes and inhibit protein synthesis, (4) they can modify the cell cycle by inducing nonapoptotic G1-phase accumulation mechanisms, G2/M phase cell cycle arrest and apoptosis, and can activate the caspase cascade, (5) lectins can also down- regulate telomerase activity and inhibit angiogenesis.

Taken together, our knowledge obtained following the oral use of plant lectins and results from numerous positive in vivo and in vitro studies provide exciting opportunities for the development of new forms of handling cancer where these molecules are incorporated into novel treatment strategies. A specific example is afforded by the soybean lectin that has been shown to have anticarcinogenic potential. González De Mejia and Prisecaru [15] 
discuss in their review potential use of lectins in cancer treatment, and correctly point out that much more research is required where both genomic and proteomic approaches should be included.

The future for lectins would seem to be promising. This further emphasises that a healthy diet should include large amounts of raw vegetables, fruit and nuts. In this way we can ensure a rich availability of these biologically active molecules that by all accounts exhibit beneficial effects on our well-being. What we need to know, however, is the stability of lectins under gastric and duodenal environments. For example, the elderberry lectins were shown by Jiménez et al [123] to be refractory to these conditions.

Most of our knowledge related to the nutritional effects of plant lectins is based on experiments using animal model systems, and only few studies have been performed on humans. The most frequently used lectin hitherto in animal studies is PHA, while equivalent studies using other types of lectins are unfortunately lacking in the literature. Since lectins are relatively specific proteins and various lectins can bind to different types of carbohydrate chains, it would therefore be incorrect to assume that PHA and ML-1-induced effects [95-100] will necessarily be characteristic for other lectins that we consume. A major reason for the frequent use of PHA is its availability since it amounts to $1-10 \mathrm{~g} / \mathrm{kg}$ raw kidney beans [111], thus representing a major protein in the bean. This is in contrast to lectins for example in onion, tomato, rice and banana where the concentration is $<0.01 \mathrm{~g} / \mathrm{kg}$ raw material [111].

Winge et al [113] performed a small pilot study to evaluate whether or not a mistletoe lectin-containing preparation taken orally by adults was able to modulate the immune system. Eight healthy individuals (mean age 47 years) took the preparation daily for a period of three months and blood samples were taken both before and during the study. All individuals demonstrated the presence of anti-lectin antibodies in the blood on day 84, showing the occurrence of an immune response. No antibodies were identified at the start of the study. At the onset of the investigation it was surprising that $50 \%$ of the healthy individuals showed NK cell levels of between 6,7 and $12,5 \%$ i.e. well-below normal values (18-40\%). Three of these showed increased levels after ingesting mistletoe lectins for 28 days, although the levels were not within normal limits During the period of observation four cell types showed a marked response: activated IL-2 helper cells, memory cells, activated T-cells and activated natural killer (NK) cells. In general the levels of activated IL-2 helper cells and memory cells were elevated on day 28 with a return to normal levels on day 84 . The levels of activated T-cells and the activated NK cells, however, were still elevated on day 84. At the start of the investigation four of the individuals had levels of NK cells that were well below normal values. At 84 days, however, three of these had values that were now within the normal range. It is likely that keeping the NK cell level within normal levels is of major importance in order to maintain a potent first line of attack against virus and bacterial infections.

It was thus evident that in order to "prime" the immune system almosta third of the individuals had to take the lectin preparation for a period of three months in order to bring their NK cell levels within the normal range [113]. Keeping the NK cell level at normal values is not only imperative for maintaining an effective first line attack against for example, virus infections, but importantly it was shown many years ago that in animals exhibting low NK cell levels then there is an increased risk for the development of both spontaneous and experimental tumours [143,144]. In addition, Yoon et al [137] showed that the prophylactic effect of a Korean mistletoe lectincontaining extract on tumour metastasis was mediated through the enhancement of the activity of NK cells. Takeda and Okumura [102] have reviewed a series of studies that have clearly identified a major role for NK cells in immune-surveillance.

The results presented here demonstrate that mistletoe lectins taken orally are effective as immunomodulators and thus a mistletoe preparation does not have to be injected (e.g. subcutaneously) in order to modulate the immune system in humans. The lectin-enriched mistletoe preparation described here appeared to effectively function as an immuno-stimulating dietary supplement for the healthy individuals who took part in the study. Of special interest was the increase in activated NK cells that was observed in several of the individuals who participated in the study. This is in line with Takeda and Okumura [102] who state that toll-like receptors and receptors to lectins, including those from mistletoe, are among the most likely candidates responsible for NK cell activation. It is interesting to note that lectins, also those from mistletoe, have recently been regarded as having great potential as anticancer agents [14]. In conclusion the mistletoe preparation described here, can be envisaged as a useful dietary supplement in order to stimulate the immune system in subjects where this would be beneficial e.g. in immunodeficiency. Such a preparation could also be beneficial for the public at large in order to "prime" the immune system such that, for example, the unpleasant effects of common colds and flu may be greatly reduced. In addition, the body will in general be more suited to combat other types of bacterial or viral infection, and, furthermore, be able to operate more effectively in the inactivation/destruction of abnormal cells in the body (e.g. cells of precancerous nature, or even tumour cells themselves).

As mentioned above there are a series of observations that clearly indicate that mistletoe lectins can induce the induction of an anti-angiogenic response. It was therefore interesting to note that serum endostatin values showed increases within a few days of the oral intake of the lectin preparation. These results would suggest that oral intake of mistletoe lectin was able to induce an anti-angiogenic response. The observed increase in TNF $\alpha$ values in 
the blood within a short time after oral intake of mistletoe lectins is in agreement with other findings showing induction of TNF $\alpha$ production following subcutaneous administration of ML [145147]. Elevated levels of $\beta$-endorphin in the blood as a result of the oral consumption of a mistletoe lectin preparation are in line with the results of Heiny and Beuth [148] and Heiny et al [149] who showed increased plasma levels of $\beta$-endorphin after treatment of breast cancer patients with standardized mistletoe lectin extracts. It is not known from this pilot study whether the observation that TNF $\alpha$ values increased in parallel with increased levels of $\beta$-endorphin values is a matter of coincidence or is indeed of some biological significance. Clearly, further work will be required to provide concrete evidence that the observed changes in endostatin, TNF $\alpha$ and $\beta$-endorphin values in response to oral intake of the mistletoe preparation are important.

Antibodies to mistletoe lectins have been detected in humans after subcutaneous administration [150-152]. We show here that the consumption of a mistletoe lectin preparation by adult's results in the induction of antibody production against mistletoe lectins. After drinking the preparation for 84 days all 8 individuals were observed to have produced ML antibodies. This is in line with previous observations where oral presentation of ML to mice resulted in the appearance of specific serum IgG and IgA antibody after three oral doses [108]. As expected different epitopes were detected since ML-I antibodies cross-react, for example with ML-III.

There are many dietary supplement preparations commercially available where claims are made that they are immunostimulatory when taken orally. Documentation of these claims, however, is in on the whole sadly lacking. In this study two lines of convincing evidence were presented that the mistletoe preparation described has potent immuno-stimulatory properties, firstly, four cell types of the immune system showed marked proliferation, and secondly, all individuals produced antibodies to the lectins present.

By using the oral, as opposed to the subcutaneous route, the possibility of an allergic reaction is reduced and a much more far-reaching, long-term effect is observed [153]. About $80 \%$ of immunoreactive tissue in the body is associated with the gastrointestinal tract. Following consumption of mistletoe lectins, they work by binding to specific galactose/N-acetylglucosamine receptors on M-cells of Peyer's patches associated with the MALT/ GALT system [78]. Subepithelial lymphoid follicles provide the most important sites for antigen sampling in the small intestine and constitute an effector mechanism for secretory immune responses of GALT [154]. The importance of this mechanism is two-fold, firstly an immune response is vital such that protection of host tissues against invading microorganisms can operate, and secondly that the extent of an infection can be curtailed as much as possible [155]. Lymphoid follicles are overlayed by the follicle-associated epithelium (FAE) that includes a number of cell types such as lymphocytes, enterocytes, goblet cells, M-cells and pre-M-cells [156]. In studies on specimens of human small intestine containing Peyer's patches Sharma et al [78] showed by histochemistry that mistletoe lectin bound to both enterocytes and M-cells of the FAE. It is therefore evident that the surface of the small intestine in humans contains receptors that bind mistletoe lectins (see Table 3 in Sharma et al [78]).

Following binding to receptors lectins causing a release of signal molecules to the blood and these are then able to stimulate the immune system and also induce an anti-angiogenic response [113]. Helper cells show a fast initial response, whereas cells involved in immuno-memory show a slower but prolonged increase. This, however, was as expected since populations of memory cells are quite stable and do not need to be activated to have an impact on the immune system as do the helper cells.

Interestingly, it was observed that the individuals who in general showed the weakest reaction were those who had initial values above normal limits, whilst those who demonstrated the highest response had values below normal at the onset of the study. The results suggest that the higher the starting (normal) values, the lower the response and vice versa, which is in agreement with other observations [102].

Although present in many foodstuffs of plant origin [14] lectins are denatured by heat treatment and thus cooking, frying etc. will reduce their immune-stimulating potential virtually to zero. Since there are many lectins which have specific receptors in the human small intestine [78] it is evident that our diet needs to contain a certain quantity of these molecules in an active form in order for them to trigger the immune system. Modern diets unfortunately provide limited amounts of active plant lectins, perhaps insufficient to achieve high-level immunosurveillance. This will mean that we will be more prone to infections and other disorders.

It has been shown that obese and diabetic patients have a greater susceptibility to develop cancer than lean and nondiabetic individuals. Furthermore, it is well known that a diet rich in saturated fats and red meats and at the same time low in fresh fruits, vegetables, and whole grains favours an increased risk of cancer. According to the United States National Institutes of Health " 12 servings of fruits and vegetables a day" can prevent the development of common diseases, including cancer [38].

In their paper Su and Tang [25] measured the lectin content in 20 non-cooked fruit and vegetable extracts (50 g amounts). Based on relative lectin levels (as measured by haemagglutination activity), what was surprising was the large differences observed: chili, Chinese cabbage, garlic, ginger, lemon and passion fruit had a content of 64, while banana, grapefruit and Kiwi had 32. Apple, 
grape and pineapple had 16 , lettuce and orange 8 , melon, onion, plum and strawberry 4 , while watermelon had 2 and carrot 1 . For example, it was interesting that lemon (64), grapefruit (32) and orange (8) i.e. all belonging to the citrus fruits, should vary by a factor of 8 .

Lectins are also ubiquitous in our food supply, mainly in legumes, like beans and soybean which can vary greatly in lectin content. Other legumes may contain $20 \mathrm{~g}$ of lectin per $100 \mathrm{~g}$ of flour. These include cereal type foods $(187.2 \mu \mathrm{g}$ of lectin/g) and texturized

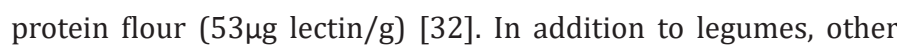
foods may contain considerable amounts of lectins, like the cereal amaranth $(8.3 \%)$, corn $(0.8 \%)$ [157]. On the other hand, meat substitutes are free in active lectin content, and extremely low levels are found in bakery products [157].

\section{The Mediterranean Diet}

If we consider a newly prepared salad that contains perhaps 10 fresh ingredients (Table 2), then the spectrum of lectins that we would be exposed to during the course of a meal, would be wide (up to 50). Perhaps the success of the Mediterranean-type diet (MedDiet), rich in plant-based material, that is now highly aclaimed for its positive effect on health, is at least in part due to a rich and varied lectin content. For the third year in a row the MedDiet has been claimed by the U.S. News and World Report as the world's best healthy diet [3]. In this class of diet, which has a high content of fruits, nuts, vegetables and whole grains, one can find $>200$ individual components that are rich in these foodstuffs (Table 1). The MedDiet has been looked at in many studies for its favourable effects on health, and professionals at the Mayo Clinic, where claims that the risk of developing cancer, Parkinson's and Alzheimers disease, and cardiovascular disease, have been put forward [158].

The MedDiet sails up as the brain's favourite food. A number of observational and intervention studies have shown that the MedDiet best protects the brain and prevents cognitive failure [159-161]. This diet consists of many unsaturated fats from olive oil, nuts and seeds, more fish and seafood, more legumes, fruit and vegetables and less grain. Around the Mediterranean they drink red wine and water for meals, not milk. They eat some dairy products in everyday life, such as sour yogurt, fresh kefir and flavoured and often unpasteurized cheeses. These are, however, extremely low in lectins. They do not eat large amounts of meat on the grill, but just stick to portions of well-ripened Parma and Serrano ham, and eat vegetables and fruit. On cool evenings, they can heat up soups of squash, broccoli, and peas, mixed with plenty of fish, and Parmesan and olives. Fresh vegetables and fruits are frozen in season and ensure good health during a cold winter.

A large study published in the British Medical Journal showed that a MedDiet with extra fat and nuts posed a much lower risk of dementia than lean diets. A total of 969 elderly (44.6\% men aged $74.6+/-5.7$ years) participated in the study. They were cognitively tested and randomized to a MedDiet with 1 liter of extra virgin olive oil per week or a MedDiet with 30 g unsalted nuts a day (15 g walnuts, $7.5 \mathrm{~g}$ hazelnuts and $7.5 \mathrm{~g}$ almonds). The control group received low-fat diets. After 6.5 years of mapping, 522 elderly persons underwent thorough neuropsychological mapping. Both MedDiet groups had far better cognitive function than those fed the lean diet [162]. The diets of olive oil and nuts worked independently of age, educational level, strain of cognitive failure in the family, dementia, cardiovascular disease, physical activity and caloric intake. The researchers explain the effect as being due to reduced inflammation and less oxidative stress. They also explain some of the effects of the MedDiet in the so-called PREDIMED study with a sharp reduction in oxidative stress using antioxidants from both red wine, espresso, extra virgin olive oil, olives, nuts and polyphenol-rich vegetables. The rest they add to a muffled inflammation throughout the body. At the same time, it is generally agreed that a Western diet rich in refined carbohydrates weakens the brain, especially the memory pathways. At the same time, scientists agree that a Western diet rich in refined carbohydrates weakens the brain, especially the memory pathways. This diet produces a malfunctioning hippocampus, and the result is impaired learning and memory.

Most experiments with lectins conducted in animals have used high doses and these have in general been conducted over relatively short periods of time. We know virtually nothing about long-term effects of exposure. It would be extremely problematical and practically difficult to test the health-related effects of plant lectins in humans. It is not such that we ingest a single type of lectin. Plant lectins are widespread in diets consisting of raw vegetables, grains, fruit and nuts and have therefore been consumed by mankind for thousands of years. From Table 1 it is evident that our food contains more than 200 lectins. The fact that fruits, vegetables and nuts can contain up to 5 different lectins means that the true number we ingest is perhaps close to 1000 .

As mentioned earlier the MedDiet provides a rich source of lectins, and persons that live for example in Greece, Italy, France and Spain are thus continually exposed to a wide variety of lectins. Their general health would appear not to be inferior to that in northern Europe, in contrast perhaps superior. One is thus tempted to conclude that a diet rich in lectins is highly advisable. For example, van Buul and Brouns [162] showed that consumption of cereals and whole grain products was associated with significantly reduced risks of cardiovascular disease, type-2 diabetes and some cancer types, where wheat germ agglutinin (WGA) is an important constituent.

In general, potential hazards of dietary lectins would appear to be unfounded. Scientific evidence currently accumulating clearly 
indicates that lectins are in fact important constituents of our diet, and will in due course be acknowledged as such along with the already well-accepted vitamins, minerals, trace elements, 3 and 6 omega fatty acids, antioxidants and fibre etc [163].

Interestingly, data presented by Rissanen et al [164] have shown that a high intake of fruit, berries and vegetables is associated with reduced risk of mortality in middle-aged Finnish men. These findings would indicate that diets rich in plant-derived foods (i.e. lectin-enriched) can promote longevity. Beattie [165] have similarly concluded that there is considerable evidence that an adequate consumption of fruit and vegetables is advisable. This is to prevent the occurence of a series of chronic diseases such as stroke, several cancers, and heart disease. More specifically Brennan et al [166] have provided data that strongly suggest a substantial protective effect on the consumption of cruciferous vegetables on lung cancer. Thole et al [167] have shown that elderberry fruits have a major chemopreventive effect on cancer development, while Pryme and Dale [122] in their review reported on the positive effect of elderberry lectins on gastrointestinal disorders.

\section{Conclusions}

There are still many unanswered questions concerning possible effects of plant lectins in our diet on general health. Results published in the literature cannot in any way be interpreted such that there are indications enabling us to suspect that dietary lectins give rise to disease. On the contrary the fact that health authorities worldwide promote the " 5 a day" (or even "7 a day") principle, namely that we should include a minimum of 5 portions of vegetables, fruit and nuts (i.e. lectin-containing foodstuffs) in our daily diet would clearly indicate that there are health-benefits associated with increased lectin intake. However, taken together there is little doubt that more intensive research efforts are required in order to be able to draw firm conclusions regarding potential health-promoting effects of dietary lectins. A major task will be to establish satisfactory scientific guidelines to pursue such studies and interpret results. It is evident that we are only at the very beginning with respect to gaining an understanding of the importance of lectins in our food with relation to health and nutrition [168-170].

\section{References}

1. Stillmark H (1888) Uber ricin, ein giftiges Ferment aus dem Sammen von Ricinus comm. Und einigen anderen Euphorbiaceen.

2. Van Damme EJM, Peumans WJ, Pusztai A, Bardocz S (1998) Handbook of Plant Lectins: Properties and Biomedical Applications. John Wiley \& Sons Ltd., Chichester, UK.

3. Pryme IF (2020) The Mediterranean Diet: Plant Lectins as Essential Components. Am J Biomed Sci \& Res 7 (2): 111-112.

4. Tanev M, Van Damme EJM (2020) 130 years of Plant Lectin Research. Glycoconjugate J 37(5): 533-551.
5. Peumans WJ, Van Damme EJM (1995) Lectins as Plant Defense Proteins. Plant Physiol 109 (2): 347-352.

6. Petersen SV, Thiel S, Jensen L, Steffensen R, Jensenius JC (2001) An assay for the mannan-binding lectin pathway of complement activation. J Immunol Meth 257(1-2): 107-116.

7. Wallis R (2002) Structural and functional aspects of complementation activation by mannose-binding protein. Immunobiology 205(4-5): 433445 .

8. Holmskov U, Thiel S, Jensenius JC (2003) Collectins and ficolins: humoral lectins of the innate immune defense. Annu Rev Immunol 21: 547-578.

9. Ashwell G, Morell AG (1974) The role of surface carbohydrates in the hepatic recognition and transport of circulating glycoproteins. Adv Enzymol Relat Areas Mol Biol 41: 99-128.

10. Nachbar M, Oppenheim JD (1980) Lectins in the US diet: A survey of lectins in commonly consumed foods and a review of the literature. Am J Clin Nutr 33 (11): 2338-2345.

11.Barondes SH (1981) Lectins: Their multiple Endogenous Cellular Functions. Ann Rev Biochem 50: 207-231.

12. Aricigil S, Pryme IF (2014) Potential beneficial effects of dietary plant lectins on health. In: Natural Products: Research Reviews 2: 1-27.

13. Liener et al (1986) Academic Press, New York.

14. Lavelle et al (2004) Immunological implications of the use of plant lectins for drug and vaccine targeting to the gastrointestinal tract. Journal of Drug Targeting 12(2): 89-95.

15. González ME, Prisecaru VL (2005) Lectins as bioactive plant proteins: A potential in cancer treatment. Crit Rev Food Sci Nutr 45(6): 425-445.

16. Chrispeels MJ, Raikhel NV (1991) Lectins, lectin genes, and their role in plant defence. Plant Cell 3(1): 1-9.

17. Grant G, More LJ, McKenzie NH, Stewart JC, Pusztai A (1983) A survey of the nutritional and haemagglutination properties of legume seeds generally available in the UK. Br J Nutr 50(2): 207-214.

18. Zhang J, Shi J, Ilic S, Xue J, Kakuda Y (2008) Biological properties and characterization of lectin from red kidney bean (Phaseolus vulgaris) Food Rev Int 25(1): 12-27.

19. Boyd WC, Reguera RM (1949) Hemagglutinating substances for human cells in various plants. J Immunol 62(3): 333-339.

20. Srinivas NK, Sandeep kK, Kolkar KP (2014) Source of lectin and betacarotene in vegetables and fruits. Indian J Appl Res 4(6): 1-3.

21. Hossani AA (1968) Hemolytic and hemagglutinating activities of 222 plants. Vox Sang. 15(6): 410-407.

22. Yariv J, Kalb AJ, Katchalski E (1967) Isolation of an L-fucose binding protein from Lotuss tetragonolobus seed. Nature 215(5103): 890-891.

23. Shudong He, Shi J, Li X, Ma Y, Xue I (2015) Identification of a lectin protein from (Phaseolus vulgaris) using LC-MS/MS and PCR method. LWT- Food Science and Technology 60(2): 1074-1079.

24. Huang Deqi, Ping YZ, Sumin Y, Zhisen L, Yuman (1992) Study on cell agglutination and sugar-inhibiting action of the lectin from Brassica olera var botrytis L. J Fujian Normal University 1992-02.

25. Su CM, Tung YC (1989) Haemagglutination activity of the fresh edible part of vegetables and fruits. J Beijing Medical College 6: 31-34.

26. Davidsen E, Stewart D (2004) Novel mannose binding lectins from agricultural crops. Industrial Crops and Products 19(2): 137-146.

27. Oii LSM, Yu H, Chen CSM, Sun SSM, Ooi VEC (2002) Isolation and characterization of a biosensitive mannose-binding protein from the Chinese chive Allium Tuberosum. J Agric Food Chem 50 (4): 696-700. 
28. Roberson BJ, Strength DR (1983) Characterization of a lectin from cowpeas. Prep Biochem 13(1): 45-56.

29. Van Damme EJM, Goldstein IJ, Peumans WJ (1991) A comparative study of mannose-binding lectins from the Amaryllidaceae and Alliaceae. Phytochemistry 30(2): 509-514.

30. Allen AK. (1979) A lectin from the exudate of the fruit of the vegetable marrow (Cucurbita pepo) that has a specificity for beta-1,4-linked $\mathrm{N}$-acetylglucosamine oligosaccharides. Biochem J 183(1): 133-137.

31. Hemperly JJ, Hopp TP, Becker JW, Cunningham BA (1979) The chemical characterization of favin, a lectin isolated from Vicia faba. J Biol Chem 254(14): 6803-6810.

32. Manage L, Joshi A, Sohonie K (1972) Toxicity to rats of purified phytohemagglutinins from four Indian legumes. Toxicon 10(1): 89-91.

33. Purkait S, Koley S (2019) Identification and characterization of lectins from Leguminosae plants. Int J Health Sciences and Research 9: 115-121

34. Khanna AK, Seagal PK (1980) Lectins: A new thought. Vox Sang 39(1): 44-45

35. Une S, Akiyama NK (2018) Lectin isolated from Japanese red sword beans (Canavalia gladiata) as a potential cancer chemopreventive agent. J Food Sci 83(3): 837-843.

36. Wong JH, Ng TB (2005) Isolation and characterization of a glucose/ mannose/rhamnose specific lectin from the knife bean Canavalia gladiata. Arch Biochem Biophys 439(1): 91-98.

37. Renkonen KO (1948) Studies on hemagglutinins present in seeds of some representatives of the family Leguminosae. Ann Med Exp Fenn 26: 66.

38. Hankins CN, Shannon LM (1978) The physical and enzymatic properties of a phytohemagglutinin from mung beans. J Biol Chem 253(21): 77917797.

39. Guruvayoorappan C, Sakthivel KM, Padmavathi G, Bakliwal V, Monisha J, et al. (2015) Cancer Preventive and Therapeutic Properties of Fruits and Vegetables: An Overview. Chapter 1.pp. 1-52, World Scientific.

40. Tsumuraya Y, Ogura K, Hashimoto Y, Mukoyama H, Yamamoto S (1988) Arabinogalactan-proteins from primary and mature roots of radish (Raphanus sativus L.). Plant Physiol 86(1): 155-160.

41. Sanadi AR, Surolia A (1994) Studies on a chitooligosaccharide-specific lectin from Coccinia indica. Thermodynamics and kinetics of umbelliferyl glycoside binding. J Biol Chem 269(7): 5072-5077.

42. Doyle RJ, Nedjat HF, Miller FRD, Keller KF (1982) Interaction between plant agglutinins and Legionella species. J Clin Microbil 15(5): 973-975.

43. Dimple A, Kumar V, Tomer V (2018) Traditional medicinal systems for treatment of diabetes mellitus: A review. Int J Pharmacy and Pharmaceut Sci 10: 7-17.

44. Kruppe M (1956) Bluttgruppenspezifische pflanzliche eiweisskorprt (Phytagglutinine). Stuttgart: Enke.

45. Kolberg J, Sletten K (1978) Isolation and partial characterisation of a mitogenic lectin from Lathyrus odoratus seeds. Acta Pathol Microbiol Scand C 86(3): 99-104.

46. Gold ER, Balding P (1975) Receptor specific proteins: Plant and animal lectins. New York: American Elsevier Publishing Co., Inc.

47. Pereira PR, Agu EMD, Verícimo AM, Zingali RB, Paschoalin VMF, et al. (2014) Purification and characterization of the lectin from taro (Colocasisa esculenta) and its effect on mouse splenocytic proliferation in vitro and in vivo. The Protein Journal 33(1): 92-99.

48. Ferriz MR, García GK, Torres AI, Rodriguez MJ, Guerrero C, et al. (2015) Tolerability assessment of a lectin fraction from Tepary bean seeds
(Phaseolus acutifolius) orally administered to rats. Toxicol Reports 2: 63-69.

49. Blasco E, Ngoc LD, Aucouturier P, Preudhomme JL, Barra A (1996) Mitogenic activity of new lectins from seeds of wild Artocarpus species from Vietnam. C R Acad Sci III 319(5): 405-409.

50. Koshte VL, Van DW, Vander SME, Aalberse RC (1990) Isolation and characterization of BanLec-I, a mannoside-binding lectin from Musa paradisiac (banana). Biochem J 272(3): 721-726.

51. Liénart Y, Gautier C, Domard A (1991) Isolation from Rubus cellsuspension cultures of a lectin specific for glucosamine oligomers Planta 184: 8-13.

52. Pineau N, Pousset JL, Preudhomme JL, Aucouturier P (1990) Structural and functional similarities of breadfruit seeds lectin and jacalin. Molecular Immunology 27(3): 237-240.

53. Sousa R, Correia MTS, Pessoa MMA, Kennedy JF, Lima-Filho JL, et al. (2001) A novel model to characterize the electric double layer of lectins from Cratylia mollis (Camaratu bean) and Canavalia ensiformis adsorbed on metallic surface. Carbohydrate Polymers 46(2): 191-193.

54. Bhat B, Shradda KJ, Chaki S (2018) Isolation and characterization of lectin from Punica granatum (pomegranate). J Bio Innov 7(1): 86-95.

55. Kabir S, Daar AS (1994) The composition and properties of jacalin, a lectin of diverse applications obtained from the jackfruit (Artocarpus heterophyllus) seeds. Immunological Investigations 23(3): 167-188.

56. Tazaki K, Shibuya N (1989) Purification and partial characterization of a lectin from the bark of Japanese elderberry (Sambucus sieboldiana). Plant Cell Physiology 30(6): 899-903.

57. Helleland SBL, Pryme IF (2012) The importance of dietary plant lectins: The blood type diet revisited. In: Medicinal Plants. Phytochemistry, Pharmacology and Therapeutics (2): 69-79.

58. Chowdhury S, Ahmed H, Chatterjee BP et al. (1987) Purification and characterization of an alpha-D-galactosyl-binding lectin from Artocarpus lakoocha seeds. Carbohydrate Research 159(1): 137-148.

59. Yeasmin T, Tang Md, Razzaque AK, Absar N (2001) Purification and characterization of three galactose specific lectins from Mulberry seeds (Morus sp.). Eur J Biochem 268(23): 6005-6010.

60. Wang TH, Kung YL, Lee MH, Su NW (2011) N-acetyl-D-galactosaminespecific lectin isolated from the seeds of Carica papaya. J Agric Food Chem 59(8): 4217-4224.

61. Kabir SR, Reza MA (2014) Antibacterial activity of Kaempferia rotunda rhizome lectin and its induction of apoptosis in Ehrlich ascites carcinoma cells. Appl Biochem Biotechnol 172(6): 2866-2876.

62. Oliveira MDL, Andrade CAS, Santos MNS, Coelho LCBB, Teixeira JA, et al. (2008) Purification of a lectin from Eugenia uniflora L. seeds and its potential antibacterial activity. Lett Appl Microbiol 46(3): 371-376.

63. Smith LM, Dinkar D, Sabnis, Johnson RPC (1987) Immunocytochemical localisation of phloem lectin from Cucurbita maxima using peroxidase and colloidal-gold labels. Planta 170(4): 461-470.

64. Coutino RR, Hernandez CP, Giles RH (2001) Lectins in fruits having gastrointestinal activity: their participation in the hemagglutinating property of Escherichia coli 0157:H7. Arch Med Res 32(4): 251-257.

65. Vyskrebentseva EI, Borisova NN (1966) Distribution of lectin activity in sugar beet mitochondria: Lectin activity of mitochondrial membranes and matrix in sugar beet taproot. Fiziol. Rast. (Moscow) 43: 527-532.

66. Peumans WI, Stinissen HM, Carlier AR (1982) Isolation and partial characterization of wheat-germ-agglutinin-like lectins from rye (Secale cereale) and barley (Hordeum vulgare). Biochem J 203(1): 239-243. 
67. Markhov EY, Khavkin EE (1982) Erythrocyte-binding properties of the stele-specific proteins in the maize seedlings root. Biochem und Physiol Pflanzen 177(9): 739-746.

68. Langston UPJ, Gade W (1984) A seed storage protein with possible selfaffinity through lectin-like binding. Plant Physiology 74(3): 675-680.

69. Hariharan K, Rao DR (1998) Haemagglutinin in Triticale. Proceedings of the Indian Academy of Sciences-Section B 87: 63-66.

70. Hamid R, Masood A (2009) Dietary lectins as disease causing toxicants. Pakistan J Nutr 8: 293-303.

71. Fraguas RM, Simao AA, Leal RS, Dos Santos CM, Rocha DA, et al. (2014) Chemical composition of processed baru (Dipteryx alata Vog.) almonds: Lyophilization and roasting. African J Agr Res 9: 1061-1069

72. Adamude FA, Nwobodo NN, Dingwoke EJ, Aguh IB, Nwosu OE (2020) Identification and characterization of lectin gene isolated from an indigenous Albizia lebbeck seeds. Scientific African 7: Article e00234.

73. Soares GSF, Assreuy AMS, Gadelha AA, Gomes VD, Delatorre P, et al. (2012) Purification and Biological Activities of Abelmoschus esculentus Seed Lectin. The Protein Journal 31(8): 674-680.

74. Lotan R, Skutelsky E, Danon D, Sharon N (1975) The purification, composition and specificity of the anti-T lectin from peanut (Arachis hypogaea). J Biol Chem 250(21): 8518-8523.

75. Datta PK, Figueroa MOR, Lajolo FM (1991) Purification and characterization of 2 major lectins from Araucaria brasiliensis syn Araucaria angustangustifolia seeds (pinhao). Plant Physiology 97(3): 856-862.

76. Prakashkumar R, Pushpangadan P, Vijayakumar T (1997) Search for lectins in seeds of tropical trees of Kerala, India. Biologia Plantarum 40: 155-158.

77. Liu B, Peng H, Yao Q, Li J, Van Damme E, et al. (2009) Bioinformatics analyses of the mannose-binding lectins from Polygonatum cyrtonema, Ophiopogon japonicus and Liparis noversa with antiproliferative and apoptosis-inducing activities. Phytomedicine 16(6-7): 601-608.

78. Sharma R, Van DEJ, Peumans WJ, Sarsfield P, Schumacher U (1996) Lectin binding reveals divergent carbohydrate expression in human and mouse Peyer's patches. Histochemistry and Cell Biology 105(6): 459-465.

79. Shao B, Wang S, Zhou J, Ke L, Rao P (2011) A novel lectin from fresh rhizome of Alisma orientale (Sam.). Process Biochem 46 (8): 1554-1559.

80. Yan Q Jiang Z, Yang S, Deng W, Han L (2005) A novel homodimeric lectin from Astragalus mongholicus with antifungal activity. Arch Biochem Biophys 442(1): 72-81.

81. Yan Q, Kumar N, Jiang Z, Huang L (2010) Characterization of a nove monomeric lectin (AML) from Astralagus membranaceus with antiproliferative activity. Food Chem 122 (3): 589-595.

82. Kheeree N, Sangvanich P, Puthong S, Karnchanatat A (2010) Antifunga and antiproliferative activities of lectin from the rhizomes of Curcuma amarissima Roscoe. Appl Biochem Biotechnol 162(3): 912-925.

83. Kabir R, Hossen A, Abu ZM, Alom J, Islam F, et al. (2011) A new lectin from the tuberous rhizome of Kaempferia rotunda: Isolation, characterization, antibacterial and antiproliferative activities. Protein and Peptide Letters 18(11): 1140-1149.

84. Gurtler LG (1978) The fucosyl specific lectins of Ulex europaeus and Sarothamnus scoparius. Biochemical characteristics and binding properties of human B-lymphocytes. Biochim Biophys Acta 544(3): 593604.

85. Zhou W, Gao Y, Xu S, Yang Z, Xu T (2014) Purification of a mannosebinding lectin Piniella ternate agglutinin and its induction of apopotosis in Bel-7404 cells. Protein Expr Purif 93: 11-17.
86. Horejsi V, Kocourek J (1974) Studies on phytohemagglutinins. XVII. Some properties of the anti-H specific phytohemagglutinin of the furze seeds (Ulex europaeus L.). Biochim Biophys Acta 336(2): 329-337.

87. Yen SE, Mansfield JM, Wallace JH (1980) The Prickly lettuce agglutinin. Isolation from leaves of the Prickly lettuce plant (Lactucasasole). Int Archives Allergy Appl Immun 61(1): 32-39.

88. Boyd WC, Waszczenko ZE, Goldwasser SM (1961) List of plants tested for hemagglutinating activity. Transfusion 1: 374-382.

89. Franz H, Ziska P, Kindt A (1981) Isolation and properties of three lectins from mistletoe (Viscum album L). Biochem J 195(2): 481-484.

90. Hankins CN, Kindinger JI, Shanon LM (1988) The lectins of Sophora japonica. II Purification, properties and N-terminal amino acid sequences of five lectins from bark. Plant Physiology 86(1): 67-70.

91. Grant G, More LJ, McKenzie NH, Dorward PM, Stewart JC, et al. (1991) A survey of the nutritional and haemagglutination properties of several tropical seeds. Livestock Research for Rural Development 3: 1-7.

92. Liu W, Hu YL, Wang M, Xiang Y, Hu Z, et al. (2002) Purification, crystallization and preliminary X-ray diffraction analysis of a novel mannose-binding lectin from Gastrodia elata with antifungal properties. Acta Crystallogr D Biol Crystallogr 58(10): 1833-1835.

93. Johnsen SP, Overvad K, Stripp C, Tjønneland A, Husted SE, et al. (2003) Intake of fruit and vegetables and the risk of ischemic stroke in a cohort of Danish men and women. Am J Clin Nutr 78: 57-64.

94. Etzler ME, Branstrator ML (1974) Differential localization of cell surface and secretory components in rat intestinal epithelium by use of lectins. J Cell Biol 62(2): 329-343.

95. Pryme IF, Pusztai A, Grant G, Bardocz S (1998) The induction of gut hyperplasia by. phytohaemagglutinin in the diet and limitation of tumour growth. Histol Histopathol 13(2): 575-583.

96. Pryme IF, Pusztai A, Bardocz S, Ewen SWB (1999) A combination of Dietary protein depletion and PHA-induced gut growth additively reduce the mass of a murine non-Hodgkin lymphoma. Cancer Lett 139(2): 145-152.

97. Pryme IF, Pusztai A, Bardocz S, Ewen SWB (2000) Dietary phytohaemagglutinin reduces growth of a murine -Hodgkin lymphoma In : Dietary Anticarcinogens and Antimutagens : Chemical and Biological Aspects (Eds. I.T. Johnson R and G. Athenaeum Press, UK.. Fenwick), pp. 350-354.

98. Pryme IF, Bardocz S, Pusztai A, Ewen SWB, Pfüller U (2004) A mistletoe lectin (ML-1)-containing diet reduces the viability of a murine nonHodgkin lymphoma tumor. Cancer Detection and Prevention 28(1): 5256.

99. Pryme IF, Bardocz S, Pusztai A, Ewen SWB (2006) Suppression of growth of tumour cell lines in vitro and tumours in vivo by mistletoe lectins. Histol Histopathol 21(3): 285-299.

100. Pryme IF, Dale TM, Tilrem P (2007) Oral mistletoe lectins: A case for their use in cancer therapy. Cancer Therapy 5: 287-300.

101. González ME, Dia VP (2010) The role of neutraceutical proteins and peptides in apopotosis, angiogenesis and metastasis of cancer cells. Cancer Metastasis Reviews 29(3): 511-528

102. Takeda K, Okumura K (2004) CAM and NK cells. Evidence Based Complementary and Alternative Medicine 1(1): 17-27

103. Pusztai A, Ewen SWB, Grant G, Peumans WJ, Van Damme EJ, et al (1990) Relationship between survival and binding of plant lectins during small intestinal passage and their effectiveness as growth factors. Digestion 46(Suppl 2): 308-316. 
104. Pusztai A, Ewen SWB, Grant G, Peumans WJ, Van Damme EJ, et al. (1995) Lectins and also bacteria modify the glycosylation of gut surface receptors in the rat. Glycoconj J 12(1): 22-35.

105. Bardocz S, Ewen SWB, Grant G, Pusztai A (1995) Lectins as growth factors for the small intestine and the gut. In: Lectins: Biomedical Perspectives, Ed. by Pusztai, A., and Bardocz, S., Taylor and Francis, London, UK, pp. 103-116.

106. Lavelle EC (1999) Lectins in oral vaccination. In: Effects of antinutrients on the nutritional value of legume diets, Eds. Bardocz S, Hajos, G, Pusztai A, COST 98 vol 6, pp. 148-156, Luxembourg

107. Lavelle EC, Grant G, Pusztai A, Pfuller U, O Hagan DT (2000) Mucosal immunogenicity of plant lectins in mice. Immunology 99(1): 30-37.

108. Lavelle EC, Grant G, Pusztai A, Pfuller U, O Hagan DT (2001) The identification of plant lectins with mucosal adjuvant activity. Immunology 102(1): 77-86.

109. Lavelle EC, Grant G, Pusztai A, Pfuller U, Leavy O, et al. (2002) Mistletoe lectins enhance immune responses to intranasally co-administered Herpes Simplex virus glycoprotein D2. Immunology 107(2): 268-274.

110. Peumans WJ, Van Damme EJM (1998) Plant lectins: Versatile proteins with important perspectives in biotechnology. Biotechnology and genetic engineering reviews 15 (1): 199-228.

111. Jordinson M, Calam J, Pignatelli M (1998) Lectins: from basic science to clinical application in cancer prevention. Expert Opinion on Investigational Drugs. 7(9): 1389- 1403.

112. Iliev ID, Funari VA, Taylor KD, Nguyen Q Reyes CN, et al. (2012) Interactions between commensal fungi and the C-type lectin receptor Dectin-1 influence colitis. Science 336(6086): 1314-1317.

113. Winge I, Dale TM, Tilrem P, Pryme IF (2010) A mistletoe lectincontaining preparation for oral use provokes an immune response and induces an increase in the population of activated natural killer cells In: Comprehensive Bioactive Natural Products Immune- modulation \& Vaccine adjuvants Ed. V.K. Gupta. vol. 5, pp.279-295. Studium Press LLC, USA. ISBN 1-933699-55-8.

114. Jordinson M, Goodlad RA, Brynes A, Bliss P, et al. (1999) Gastrointestinal responses to a panel of lectins in rats and maintained on total parenteral nutrition. American Journal of Physiology 276(5): G12351242.

115. Freed D (1991) Lectins in food: Their importance in health and disease. J Nutrit and Med 2(1): 45-64.

116. Banwell, JG, Howard R, Cooper D, Costerton JW (1985) Intestinal microbial flora after feeding phytohaemagglutinin lectins (Phaseolus vulgaris) to rats. Applied and Environmental Microbiology 50(1): 6880 .

117. Koninkx JF, Brown DS, Kok W, Hendriks H, Pusztai A, et al. (1996) Polyamine metabolism of enterocyte-like Caco-2 cells after exposure to Phaseolus vulgaris lectin. Gut 38(1): 47-52.

118. Pusztai A, Bardocz S, Ewen SWB (2008) Uses of plant lectins in bioscience and biomedicine. Frontiers in Bioscience 13: 1130-1140.

119. Vasconcelos IM, Oliveira JT (2004) Antinutritional properties of plant lectins. Toxicon 44(4): 385-403.

120. Kordas K, Szalmay G, Bardocz S, Pusztai A, Varga G (2001) Phytohaemagglutinin inhibits gastric acid but not pepsin secretion in conscious rat. Journal of Physiology, Paris 95(1-6): 309-314.

121. Mach L, Scherf W, Ammann M, Poetsch J, Bertsch W, et al. (1991) Purification and partial characterization of a novel lectin from elder (Sambucus nigra L) fruit. Biochemical J 278(Pt 3): 667-671.

122. Pryme IF, Dale TM (2016) Elderberry (Sambucus nigra), its constituents and use in treating gastrointestinal ailments. In: Medicinal Plants: Phytochemistry, Pharmacology and Therapeutics Vol. 4, pp. 197-222
123. Jimenez P, Cabrero P, Cordoba DD, Cordoba DM, Garrosa M, et al. (2017) Lectin digestibility and stability of elderberry antioxidants to heat treatment in vitro. Molecules 22(1): 95.

124. Chatterjee A, Yasmin T, Bagchi D, Stohs SJ (2004) Inhibition of Helicobacter pylori in vitro by various berry extracts, with enhanced susceptibility to clarithromycin. Mol Cell Biochem 265(1-2): 19-26.

125. Charlebois D (2007) Elderberry as a medical plant. In: Issues in new crops and new uses, Ed. Janick, J. and Whipkey, A. ASHS press Alexandria, VA. pp. 284-292.

126. Cejpek K, Malouskova I, Koneny M, Velisek J (2009) Antioxidant activity in variously prepared elderberry foods and supplements. Czech J Food Sci 27: 45-48.

127. Sreedhar AS, Csermely P (2004) Heat shock proteins in the regulation of apoptosis: new strategies in tumor therapy. Pharmacology and Therapeutics 101(3): 227-257.

128. Nylandsted J, Jäättelä M (2004) Heat shock protein 70: en vigtig overlevelses faktor for kræftceller. Ugeskr Laeger 166: 3184-3186.

129. Ciocca DR, Clark GM, Tandon AK, Fuqua SA, Welch WJ, et al. (1993) Heat shock protein hsp70 in patients with axillary lymph nodenegative breast cancer: progressive implications. J Natl Cancer Inst 85(7): 570-574.

130. Lin J, Wu X, Chen J, Chang A, Levine AJ (1994) Functions of the p53 protein in growth regulation and tumor suppression. Cold Spring Harbor Symposium on Quantitative Biology 59: 215-223.

131. Vargas RLM, Gago FE, Tello O, Aznar JC, Ciocca DR (1998) Heat shock protein expression and drug resistance in breast cancer patients treated with induction chemotherapy. International Journal of Cancer 79(5): 468-75.

132. Rohde M, Daugaard, M, Jensen MH, Helin K, Nylandsted J, et al. (2005) Members of the heat-shock protein 70 family promote cancer cell growth by distinct mechanisms. Genes and Development 19(5): 570582.

133. Nylandsted J, Gyrd HM, Danielewicz A, Fehrenbacher N, Lademann U, et al. (2004) Heat Shock Protein 70 Promotes Cell Survival by Inhibiting Lysosomal Membrane Permeabilization. J Exp Med 200 (4): 425-435.

134. Pusztai A, Stewart JC (1978) Isolectins of Phaseolus vulgaris. Physicochemical studies. Biochimica Biophysica Acta 536(1): 38-49.

135. Yoon TJ, Yoo YC, Choi OB, Do MS, Kang TB, et al. (1995) Inhibitory effect of Korean mistletoe (Viscum album coloratum) extract on tumor angiogenesis and of hematogenous and non-hematogenous tumor cells in mice. Cancer Letters 97(1): 83-91.

136. Yoon TJ, Yoo YC, Kang TB, Shimazaki K, Song SK, et al. (1999) Lectins isolated from Korean mistletoe (Viscum album coloratum) induce apoptosis in tumour cells. Cancer Letters 136(1): 33-40.

137. Yoon TJ, Yoo, YC, Kang TB, Song S, Lee KB, et al. (2003) Antitumor activity of the Korean mistletoe lectin is attributed to activation of macrophages and NK cells. Archives of Pharmacol Research 26: 861867.

138. Pryme IF (2012) Mistletoe lectins in cancer therapy: Administration by the oral route or by subcutaneous injection? A review. In: Natural Products: Research Reviews vol. 1, pp. 79-9. ISBN 978-81-7035-755-9

139. Coelho CBB, Silva PMDS, Lima VLDM, Pontual EV, Paiva PMG, et al. (2017) Lectins, interconnecting proteins with biotechnological/ pharmacological and therapeutic applications. Evid Based Complement Alter Med

140. Ferriz MR, Garcia GK, Torres AI (2015) Tolerability assessment of a lectin fraction from Tepary bean seeds (Phaseolus acutifolius) orally administered to rats. Toxicology Reports 2: 63-69. 
141. Kabir SR, Nabi MM, Nurujjaman M, Reza MA, Alam AK, et al. (2015) Momordica charantia seed lectin: toxicity, bacterial agglutination and antitumor properties. Appl Biochem Biotechnol 175(5): 2616-2628.

142. D’Adamo and Whitney (1996) Eat Right 4 Your Type. G.P Putnam's Sons.

143. Talmadge JE, Meyers KM, Prieur DJ, Starkey JR (1980) Role of NK cells in tumour growth and metastasis in beige mice. Nature 284(5757) 622-624.

144. Gorelik E, Wiltrout RH, Okumura K, Habu S, Herberman RB (1982) Role of NK cells in the control of metastatic spread and growth of tumor cells in mice. International Journal of Cancer 30(1): 107-112.

145. Hajtó T, Hostanska K, Frei K, Rordorf C, Gabius HJ (1990) Increased secretion of tumor necrosis factor alpha, interleukin 1, interleukin 6 by human mononuclear cells exposed to beta-galactoside-specific lectin from clinically applied mistletoe extract. Cancer Research 50(11): 3322-3326

146. Männel DN, Becker H, Gundt A, Kist A, Franz H (1991) Induction of tumor necrosis factor expression by a lectin from Viscum album. Cancer Immunology and Immunotherapy 33(3): 177-182.

147. Stein GM, Henn W, Von Laue H, Berg P (1998) Modulation of the cellular and humoral immune responses of tumour patients by mistletoe therapy. European Journal of Medical Research 3(4): 194-202.

148. Heiny BM, Beuth J (1994) Mistletoe extract standardized for the galactoside- specific lectin (ML-I) induces beta-endorphin release and immunopotentiation in breast cancer patients. Anticancer Research 14(3B): 1339-1342.

149. Heiny BM, Albrecht V, Beuth J (1998) Correlation of immune cell activities and beta-endorphin release in breast carcinoma patients treated with galactose-specific lectin standardized mistletoe extract. Anticancer Research 18(1B): 583-586.

150. Stettin A, Schultze JL, Stechemesser E, Berg PA (1990) Anti-mistletoe lectin antibodies are produced in patients during therapy with an aqueous mistletoe extract derived from Viscum album L. and neutrale lectin-induced cytotoxicity in vitro. Klinische Wochenschrift 68(18): 896-900.

151. Stein GM, Stettin A, Schultze J, Berg PA (1997) Induction of antimistletoe lectin antibodies in relation to different mistletoe-extracts. Anticancer Drugs 8 (Suppl. 1): 57-59.

152. Klein R, Classen K, Berg PA, Ludtke R, Werner M, et al. (2002) In vivo- induction of antibodies to mistletoe lectin-1 and viscotoxin by exposure to aqueous mistletoe extracts: a randomised double-blinded place bo-controlled phase I study in healthy individuals. European Journal of Medical Research 7(4):155-163.

153. Roy MJ, Ruiz A, Varvayanis M (1987) A novel antigen is common to the dome epithelium of gut- and bronchus-associated lymphoid tissues. Cell and Tissue Research 248(3): 635-644

154. Kraehenbuhl JP, Neutra MR (1992) Molecular and cellular basis of immune protection of mucosal surfaces. Physiological Reviews 72(4): 853-879.
155. Gebert A, Hach G (1993) Differential binding of lectins to M cells and enterocytes in the rabbit cecum. Gastroenterology 105(5): 1350-1361.

156. Martinez CM, Zenteno T, Córdoba F (2001) Purification and characterization of a galactose-specific lectin from corn (Zea mays) coleoptile. Biochimica et Biophysica Acta 1568(1): 37-44.

157. Calderon AM, Moreno LV, Robles MR (2003) Active soybean lectin in foods: Isolation and quantitation by ELISA using immobilized asialofetuin. Food Research International 36(8): 815-821.

158. Estruch R, Ros E, Salas SJ, Covas MI, Corella D, et al. (2018) Primary prevention of cardiovascular disease with a Mediterranean diet supplemented with extra virgin-oil or nuts. New Engl J Med 378: 34.

159. Van RO, Berendsen AAM, Haveman NA, Groot LCP (2015) Dietary patterns, cognitive decline, and dementia: A systematic review. Adv Nutr 6(2): 154-168.

160. Cao L, Tan L, Wang HF, Jian T, Zhu XC, et al. (2016) Dietary patterns and risk of dementia: a systematic review and meta-analysis of cohort studies. Mol Neurobiol 53(9): 6144-6154.

161. Martínez Lapiscina EH, Clavero P, Toledo E, Estruch R, Salas SJ, et al. (2013) Mediterranean diet improves cognition: The PREDIMEDNAVARRA randomized trial. J Neurol Neurosurg \& Psych 84(12): 13181325

162. Van Buul VJ, Brouns F (2014) Health effects of wheat lectins: A review. J Cereal Sci 59(2): 112-117.

163. Oruch R, Pryme IF (2012) The biological significance of vitamin A in humans : A review of nutritional aspects and clinical considerations. Science Jet 1: 19.

164. Rissanen TH, Voutilainen S, Virtanen JK, Venho B, Vanharanta M, et al. (2003) Low intake of fruits, berries and vegetables is associated with excess mortality in men: the Kuopio Ischaemic Heart Disease Risk Factor (KIHD) Study. Journal of Nutrition 133(1): 199-204.

165. Beattie J, Crozier A, Duthie GG (2005) Potential health benefits of berries. Current Nutrition and Food Science 1: 71-86.

166. Brennan P, Hsu CC, Moullan N, Szeszenia DN, Lissowska J, et al. (2005) Effect of cruciferous vegetables on lung cancer in patients stratified by genetic status: a mendelian randomisation approach. Lancet 366(9496): 1558-1660.

167. Thole JM, Burns Kraft TF, Sueiro LA, Kang YH, Gills JJ, et al. (2006) A comparative evaluation of the anticancer properties of European and American elderberry fruits. J Medicinal Food 9(4): 498-504.

168. Boyd WC (1954) The Proteins, vol. 2 part 2.

169. Rissanen TH, Voutilainen S, Virtanen JK, Venho B, Vanharanta M, et al. (2003) Low intake of fruits, berries and vegetables is associated with excess mortality in men: the Kuopio Ischaemic Heart Disease Risk Factor (KIHD) Study. Journal of Nutrition 133(1): 199-204.

170. Jolly C, Morimoto RI (2000) Role of the heat-shock response and molecular chaperones in oncogenesis and cell death. J Natl Cancer Inst 92(19): 1564-1572. 